\title{
Retro-Commissioning a Performing Arts Center using HVAC-Cx
}

\author{
Natascha Milesi Ferretti, P.E. \\ Michael A. Galler \\ Steven T. Bushby \\ Robert W. Leader \\ J. Michael Whitcomb, P.E. \\ David W. Rush, P.E.
}

This publication is available free of charge from:

https://doi.org/10.6028/NIST.TN.2027

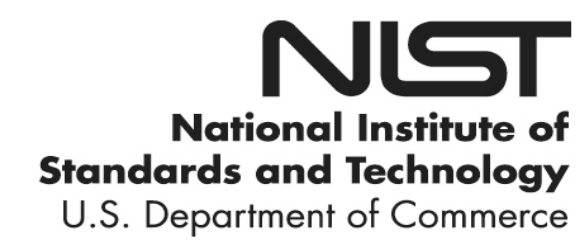




\section{Retro-Commissioning a Performing Arts Center using HVAC-Cx}

Natascha Milesi Ferretti, P.E. Michael A. Galler

Steven T. Bushby

Building Environment Division

Engineering Laboratory

Robert W. Leader Arizona State University

J. Michael Whitcomb, P.E. Montgomery College

David W. Rush, P.E. Facility Dynamics Engineering

This publication is available free of charge from: https://doi.org/10.6028/NIST.TN.2027

February 2019

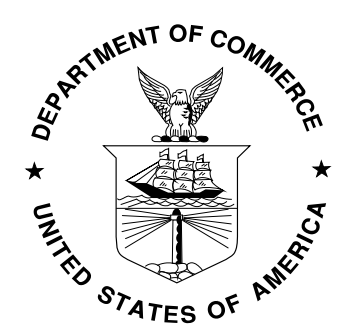

U.S. Department of Commerce Wilbur L. Ross, Jr., Secretary

National Institute of Standards and Technology Walter Copan, NIST Director and Undersecretary of Commerce for Standards and Technology 
Certain commercial entities, equipment, or materials may be identified in this document in order to describe an experimental procedure or concept adequately. Such identification is not intended to imply recommendation or endorsement by the National Institute of Standards and Technology, nor is it intended to imply that the entities, materials, or equipment are necessarily the best available for the purpose.

National Institute of Standards and Technology Technical Note 2027

Natl. Inst. Stand. Technol. Tech. Note 2027, 34 pages (February 2019) CODEN: NTNOEF

This publication is available free of charge from:

https://doi.org/10.6028/NIST.TN.2027 


\begin{abstract}
This report presents the use of a semi-automated commissioning tool for the energy retrocommissioning of the Performing Arts Center at Montgomery College in Rockville, Maryland. Researchers and field practitioners collaborated to implement the HVAC-CX commissioning software tool in its first full-scale field test. HVAC-Cx aids building operators in decision-making by analyzing data using a set of expert rules governing the operation of the mechanical equipment. This publically-available software program has the capability to communicate with BACnet controllers to command the systems under test into their various modes of operation and to record system responses to facilitate some of the labor-intensive activities of retro-commissioning. These activities included monitoring building data under normal operation (operation monitoring) and active testing using a library of prefunctional tests and functional performance tests developed to evaluate the performance of both air-side and water-side systems. This report presents the results of the commissioning process and examines the effectiveness of the HVAC-Cx commissioning tool.
\end{abstract}

\title{
Key words
}

HVAC-Cx; building commissioning; air-handling units; chilled water supply; expert rules; fault detection; functional performance. 


\section{Table of Contents}

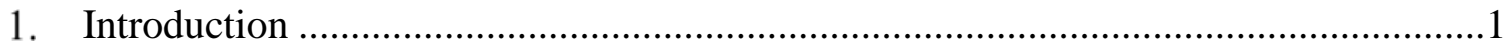

2. Performing Arts Center Site Description and Retro-Cx Test Plan................................

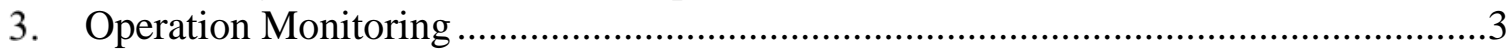

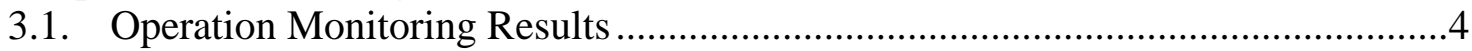

3.1.1. Chilled Water Distribution System Findings ……….........................................4

3.1.2. Air-Handling System Findings......................................................................

4. Active Testing....................................................................................................10

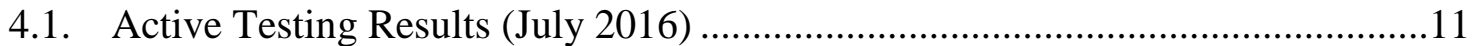

4.1.1. Chilled Water Distribution System Findings ...................................................11

4.1.2. Air-Handling System Findings...................................................................14

4.1.3. Miscellaneous Findings ...............................................................................18

5. Lessons Learned for HVAC-Cx and Next Steps ....................................................19

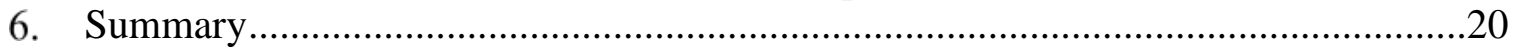

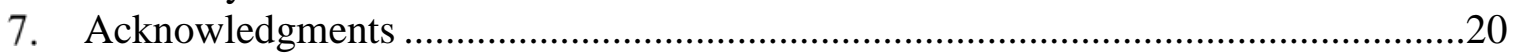

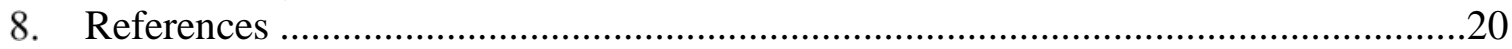

Appendix A: PA Chilled Water System Description.........................................................23

Appendix B: PA Air-Handling System Description..........................................................25

Appendix C: Library of Active Test Scripts ................................................................27

\section{List of Tables}

Table 1: Findings from Operation Monitoring of the PA Chiller Loop .............................. 4

Table 2: Findings from Operation Monitoring of the PA Air-Handling Unit ..................... 8

Table 3: Findings from the Pre-functional and Active Cx Tests of the PA Chilled Water

Loops

Table 4: Summary of Active Testing of the Chiller Loop ............................................... 13

Table 5: Findings from Pre-functional and Active Testing of the PA AHUs..................... 14

Table 6: Miscellaneous Findings .................................................................................... 18

Table A-1: Valve and Pump Sequencing for Chilled Water from PA Control System.... 23

Table C-1: List of Test Scripts to Retro-Cx the PA Chilled Water Distribution System . 27

Table C-2: List of Active Test Scripts to Retro-Cx the PA Air-Handling System........... 29

\section{List of Figures}

Figure A-1: Flow diagram for building chilled water......................................................... 24

Figure B-1: Flow diagram for AHU-1A. ...................................................................... 26 


\section{Introduction}

Commissioning ${ }^{1}(\mathrm{Cx})$ is a quality control process applied to new construction or existing buildings to ensure proper system operation. It forms a foundation for cost-effective building operations and maintenance (O\&M) and can reduce lifecycle costs, decrease energy use, and improve occupant comfort and productivity [2, 3, 4, 5, 6]. However, application of the $\mathrm{Cx}$ process is not uniform. There are challenges in assuring high quality, which is greatly influenced by the experience of the commissioning authority and the scope of the effort.

To maintain system performance, building operators must identify issues as they arise throughout the building lifecycle, preferably before comfort and performance are negatively impacted. Cx activities are intended to provide this feedback to the operators. There are two basic types of $\mathrm{Cx}$, initial building $\mathrm{Cx}$ (ICx) for new construction, and existing building $\mathrm{Cx}(\mathrm{EBCx})$ [7]. EBCx is used to improve the operation of facilities and systems relative to specific and current facility requirements and includes retro- $\mathrm{Cx}$, the application of the $\mathrm{Cx}$ process to an existing facility that was not previously commissioned, and re-Cx, which is the application of the $\mathrm{Cx}$ process to an existing facility that was originally delivered using the $\mathrm{Cx}$ process.

ICx can have the greatest impact on the lifetime performance of an individual building because issues can be identified earlier and more easily remedied. However, the EBCx process applied to the existing building stock can have a greater overall national impact on productivity and energy use because of the vast number of existing buildings. The $\mathrm{Cx}$ process is best executed with a thorough ICx and subsequent re-Cx efforts to evaluate ongoing system operations to provide building operators the feedback needed to ensure persistence of proper operation. Regardless of Cx type, the building industry is challenged to improve quality, consistency, and return on investment of $\mathrm{Cx}$ on a national scale; tools are needed to address these challenges $[4,8]$.

Automation can help carry out labor-intensive parts of the Cx process. It is a means to address the challenge of scaling up $\mathrm{Cx}$ services, increasing both the scope and depth of testing. Automated $\mathrm{Cx}$ tools can support pre-functional testing and functional performance testing and operation monitoring. Pre-functional testing involves on-site inspections of the systems, comparisons with design documentation, basic testing of component functionality, such as dampers opening and closing on command. Functional performance testing evaluates how components work together using control sequences to meet the design intent. Operation monitoring evaluates system operation over a wide range of normal system operation. Conducting such performance testing for all mechanical equipment can be cost prohibitive, but automation can reduce cost. Cx providers or building operators can use $\mathrm{Cx}$ tools carry out active testing, delivering commands through building controllers to invoke a response from a component or system. Analysis of the system's response can be carried out manually, or automated to confirm that the response is appropriate [9].

1 Commissioning (Cx) Process: a quality-focused process for enhancing the delivery of a project. The process focuses on verifying and documenting that the facility and all of its systems and assemblies are planned, designed, installed, tested, operated, and maintained to meet the Owner's Project Requirements (OPR). [1] 
The National Institute of Standards and Technology (NIST) developed HVAC-Cx [10], a publicly-available software tool designed to automate $\mathrm{Cx}$ for heating, ventilating, and air conditioning (HVAC) equipment in buildings. It can be used for ongoing monitoring under normal conditions and provides the ability to detect faults related to improper operation using expert rules to identify the most likely fault causes and to document results. The goal is to improve system performance in terms of occupant comfort, energy management and equipment life, and reduce cost. It was conceived exclusively for commercial buildings equipped with one or more air-handling units (AHUs), terminal units, hot water loops, chilled water loops, and chillers. The built-in Cx rules developed for these equipment types can be applied and/or custom rules can be introduced.

HVAC-Cx aids building operators by analyzing data collected from the building automation system (BAS) and evaluating the data using a set of expert rules governing the proper operation of the mechanical equipment. Simplified results are presented in the forms of graphs and tables, and diagnostic assistance is provided through a list of possible causes for each fault detected.

In earlier work, HVAC-Cx was validated in a laboratory environment using the Virtual Cybernetic Building Testbed [12,13]. Next, the tool was used to evaluate the field performance of chiller loops and air-handling units in the Robert E. Parilla Performing Arts Center (PA) at Montgomery College in Rockville, Maryland, using ongoing monitoring of real building operating data [14,15]. The findings were used by the Facilities Energy Manager at Montgomery College to initiate a full retro-Cx of the PA chiller loops and air-handling units.

This report documents the retro-Cx process and results from both operation monitoring and active testing of the PA, including both pre-functional tests and functional performance tests. This study also examines the effectiveness of HVAC-Cx for retro-Cx.

\section{Performing Arts Center Site Description and Retro-Cx Test Plan}

Built in 1984, the Robert E. Parilla Performing Arts Center (PA) is a 2600 gross $\mathrm{m}^{2}$ $\left(28000 \mathrm{ft}^{2}\right)$ building that houses a 500-seat auditorium, a lobby area, a dressing area, a green room, an administrative office, a shop area, and two mechanical rooms. There are two floors and a partial basement. In 2008, the mechanical and electrical systems were replaced [16]. The replacement project included:

- All air-handling units and exhaust fans;

- The existing chiller and cooling tower, chilled water and heating water pumps, and installation of a new chilled water line that interfaces to the campus central plant loop;

- The fire detection/alarm system and sprinkler system;

- Interior and exterior lighting (excluding theatrical lighting);

- New electrical service entrance; and

- A new BAS with occupancy scheduling capabilities for the mechanical equipment.

The PA chilled water system and air-handling system are described further in Appendices A and B, respectively. The building's mechanical and electrical systems and sequences of operation [17] were never commissioned as a part of the replacement project. 
In the years following the replacement project, performance issues arose. Comfort complaints were reported by occupants in the auditorium and lobby areas. This led O\&M staff to take actions that were intended to address those comfort complaints but had negative impacts on energy efficiency and equipment life, as well created comfort issues in other areas. For example, the O\&M staff noticed that the air-handling units were no longer capable of responding to increased loads during performances. O\&M staff responded by maintaining a lower setpoint of $20^{\circ} \mathrm{C}\left(68^{\circ} \mathrm{F}\right)$ around the clock. This satisfied the major complaints for the auditorium and lobby areas but necessitated the use of space heaters in the offices. Over time, both occupants and O\&M staff deemed the performance of the HVAC system to be poor. To initiate the investigation of the poor HVAC performance at the PA, three months of data were collected by NIST in 2015 and analyzed using only the operation monitoring features of HVAC-Cx. The Cx team used site visits to verify findings. The results indicate that HVAC-Cx can successfully detect common HVAC faults through operation monitoring using field data, but the ability to evaluate the system response under a variety of operating modes is dependent on the seasonal weather fluctuations [14]. Furthermore, performance of the HVAC-Cx automated analysis would likely improve by expanding the rule base to capture those faults that were detected by NIST using HVAC-Cx graphing capabilities. A recommendation for a full retro-Cx process was also made by NIST and the Cx Agent to Montgomery College.

In June 2016, the Montgomery College energy manager created a team to retro-Cx both the water-side and air-side systems (chiller loops and air-handling units). The team consisting of representatives from NIST, a Cx agent, contractors from the controls company and facilities staff (listed in Section 7, Acknowledgements). The team formulated a plan to carry out operation monitoring using available recorded data and active testing, using HVAC-Cx to assist in pre-functional testing and functional performance testing of the selected systems.

\section{Operation Monitoring}

Following the initial team site visit, NIST began collecting data from the BAS to monitor building operation under normal conditions. Data for the chiller water supply loops and the air handlers was collected from the BACnet control systems. Device data was recorded from sensors, motors, and dampers, including alarms and mode status. The data from March 2016 through July 2016 were analyzed in HVAC-Cx to detect performance faults and to note trends that were indicative of system performance and compliance issues with the documented sequences of operation.

The data was analyzed by HVAC-Cx on a minute-by-minute basis to determine whether operation was consistent with a set of logical expert rules based on the documented sequence of operations, physical models, and additional information and alarms provided by the devices themselves. A diagnostic report is automatically generated. It contains the list of faults triggered and possible causes for each hour. HVAC-Cx users can review the faults that occurred in a minute and an hour, and over a day through the graphical user interface (GUI). The fault categories are presented in Section 3.1, while details of the individual findings are presented in Sections 3.1.1 and 3.1.2. From this daily diagnostic report, a building operator or $\mathrm{Cx}$ agent could decide to inspect the individual components that indicated faults or implement specific tests for the components in question. 


\subsection{Operation Monitoring Results}

Much was learned about the PA systems from the operation monitoring and analysis. Findings from this analysis of the chilled water distribution system and the air-handling system are presented in Tables 1 and 2, respectively. The 'Fault \#' is an identifier that will be used throughout the discussion, ' $\mathrm{CL}$ ' indicates it is a chiller loop finding, while 'AH' indicates an AHU finding. The 'Component' identifies which part of the system was involved. 'Finding' summarizes the fault type and then provides specific findings for that component. The findings are representative of the different types of faults that one can detect using HVAC-Cx. The italicized fault descriptions which preface the faults are categorized as follows:

- Control sequence implementation fault: A control sequence that is prescribed in the documentation that was found to not have been implemented in the system.

- Control logic fault: There is a control sequence for this mode of operation, but it yields poor performance or efficiency.

- Sensor fault: A sensor needs to be recalibrated, is broken, or is not connected properly.

- Mechanical fault: A mechanical component of a loop or duct is broken, unresponsive, or does not perform its full range of motion.

- Maintenance fault: Routine cleaning or replacement of parts needs to be done.

- Documentation fault: The documentation does not accurately represent the state of the system, and either the control sequences or the documentation needs updating.

The 'Detection Method' column documents the Cx activity that led to the finding. There are two basic ways that this occurred: 1) using HVAC-Cx to apply expert rules to performance data and recording the findings, listed in Tables 1, 2, and 3 as 'Applying HVAC-Cx Rules', or 2) observing trend data using the graphical user interface, listed in Tables 1, 2, and 3 as 'Analyzing Graphs in HVAC-Cx' (though this could also be accomplished through any operator interface with trending capabilities). In the 'Resolution or Recommendation' column of the tables, resolutions to the findings are listed first in plain text and recommendations that have not yet been implemented are boldfaced. The 'Fault Impact' column of the table documents which aspects of performance are likely to be negatively impacted, such as, equipment life, energy usage, occupant comfort, or a building operator's understanding of system operations (operator training).

\subsubsection{Chilled Water Distribution System Findings}

Key findings from pre-functional testing of the chilled water distribution system can be viewed in two categories: 1 ) issues with equipment performance, and 2) issues with the implementation of the sequences of operation. In both cases, HVAC-Cx provided useful insight that complemented the physical inspection of the system. Appendix A presents the component names used throughout this report, along with a more detailed description of the valve and pump sequencing specified for the chilled water loop. 
Table 1: Findings from Operation Monitoring of the PA Chiller Loop

\begin{tabular}{|c|c|c|c|c|c|}
\hline Fault \# & Component & Finding & $\begin{array}{l}\text { Detection } \\
\text { Method }\end{array}$ & $\begin{array}{l}\text { Resolution or } \\
\text { Recommendation }^{2}\end{array}$ & $\begin{array}{l}\text { Fault } \\
\text { Impact }\end{array}$ \\
\hline CL1 & $\begin{array}{l}\text { T-1 (Plant } \\
\text { chilled water } \\
\text { supply } \\
\text { temperature } \\
\text { sensor) }\end{array}$ & $\begin{array}{l}\text { Sensor fault: The } \\
\text { sensor is reading } \\
\text { values that are } \\
\text { approximately } \\
5^{\circ} \mathrm{C}\left(9^{\circ} \mathrm{F}\right) \text { above } \\
\text { the actual } \\
\text { temperature of the } \\
\text { water. }\end{array}$ & $\begin{array}{l}\text { Analyzing } \\
\text { temperature } \\
\text { graphs in } \\
\text { HVAC-Cx. }\end{array}$ & $\begin{array}{l}\text { It is recommended that } \\
\text { this sensor be } \\
\text { recalibrated. If this does } \\
\text { not work, then it should } \\
\text { be replaced. }\end{array}$ & $\begin{array}{l}\text { Equipment } \\
\text { life } \\
\text { Energy } \\
\text { Usage }\end{array}$ \\
\hline CL2 & BTU meter & $\begin{array}{l}\text { Sensor fault: The } \\
\text { combined sensors } \\
\text { that detect heat } \\
\text { content, flow rate, } \\
\text { and temperature in } \\
\text { both the chiller } \\
\text { and hot water } \\
\text { loops, are broken } \\
\text { and report default } \\
\text { values. }\end{array}$ & $\begin{array}{l}\text { Analyzing } \\
\text { graphs in } \\
\text { HVAC-Cx } \\
\text { and visual } \\
\text { inspection. }\end{array}$ & $\begin{array}{l}\text { It is recommended that } \\
\text { these be replaced with } \\
\text { another BACnet } \\
\text { compatible sensor so that } \\
\text { these values may be } \\
\text { monitored as they are in } \\
\text { important locations in } \\
\text { the loops. }\end{array}$ & $\begin{array}{l}\text { Operator } \\
\text { training } \\
\text { Equipment } \\
\text { life }\end{array}$ \\
\hline CL3 & $\begin{array}{l}\text { AHU Chilled } \\
\text { Water Valve } \\
\text { Strainers }\end{array}$ & $\begin{array}{l}\text { Maintenance } \\
\text { fault: Not cleaning } \\
\text { the valve strainers } \\
\text { had led to poor } \\
\text { operating } \\
\text { conditions and } \\
\text { cooling capability. }\end{array}$ & $\begin{array}{l}\text { Analyzing } \\
\text { graphs in } \\
\text { HVAC-Cx } \\
\text { and } \\
\text { confirming } \\
\text { with visual } \\
\text { inspection. }\end{array}$ & $\begin{array}{l}\text { The valve strainers were } \\
\text { cleaned, leading to a } \\
\text { significant increase in flow } \\
\text { through the coils and } \\
\text { system efficiency. It is } \\
\text { recommended that the } \\
\text { new strainers be easily } \\
\text { accessible through the } \\
\text { insulation for future } \\
\text { maintenance and that } \\
\text { strainer cleaning be } \\
\text { added to the regular } \\
\text { maintenance schedule. }\end{array}$ & $\begin{array}{l}\text { Energy } \\
\text { usage } \\
\text { Occupant } \\
\text { comfort } \\
\text { Equipment } \\
\text { life }\end{array}$ \\
\hline CL4 & $\begin{array}{l}\text { V-4 (bypass } \\
\text { valve) } \\
\text { Mode } 3 \mathrm{~b}\end{array}$ & $\begin{array}{l}\text { Control sequence } \\
\text { implementation } \\
\text { fault: bypass valve } \\
\text { not opening. }\end{array}$ & $\begin{array}{l}\text { Applying } \\
\text { HVAC-Cx } \\
\text { rules. }\end{array}$ & $\begin{array}{l}\text { Resolution: The control } \\
\text { logic was updated to have } \\
\text { the mode sequence control } \\
\text { the correct BACnet object. }\end{array}$ & $\begin{array}{l}\text { Equipment } \\
\text { life }\end{array}$ \\
\hline
\end{tabular}

\footnotetext{
${ }^{2}$ Recommendations that have not yet been implemented are boldfaced
} 


\begin{tabular}{|c|c|c|c|c|c|}
\hline Fault \# & Component & Finding & $\begin{array}{l}\text { Detection } \\
\text { Method }\end{array}$ & $\begin{array}{l}\text { Resolution or } \\
\text { Recommendation }^{2}\end{array}$ & $\begin{array}{l}\text { Fault } \\
\text { Impact }\end{array}$ \\
\hline CL5 & $\begin{array}{l}\text { V-1 (Chilled } \\
\text { water return } \\
\text { valve) }\end{array}$ & $\begin{array}{l}\text { Control sequence } \\
\text { implementation } \\
\text { fault: Valve was } \\
100 \% \text { open but } \\
\text { should modulate } \\
\text { to control heat } \\
\text { load on campus } \\
\text { loop. }\end{array}$ & $\begin{array}{l}\text { Analyzing } \\
\text { graphs in } \\
\text { HVAC-Cx } \\
\text { and } \\
\text { confirming } \\
\text { with visual } \\
\text { inspection. }\end{array}$ & $\begin{array}{l}\text { Valve } 1 \text { needed to } \\
\text { modulate to maintain an } \\
8.3^{\circ} \mathrm{C}\left(15^{\circ} \mathrm{F}\right) \text { difference } \\
\text { across the building supply } \\
\text { and return temperature. A } \\
\text { point representing this } \\
\text { difference was created in } \\
\text { the BAS to implement this } \\
\text { requirement. }\end{array}$ & $\begin{array}{l}\text { Energy } \\
\text { usage }\end{array}$ \\
\hline$\overline{\text { CL6 }}$ & $\begin{array}{l}\text { V-2 (Plant } \\
\text { supply valve) } \\
\text { and V-3 } \\
\text { (Chiller } \\
\text { return valve) }\end{array}$ & $\begin{array}{l}\text { Documentation } \\
\text { fault: Control } \\
\text { sequence } \\
\text { documentation } \\
\text { described valve } \\
\text { sequences of } \\
\text { operation in } \\
\text { conflict with the } \\
\text { programmed } \\
\text { mode sequences. } \\
\text { The programmed } \\
\text { sequences were } \\
\text { verified as correct. }\end{array}$ & $\begin{array}{l}\text { Applying } \\
\text { HVAC-Cx } \\
\text { rules. }\end{array}$ & $\begin{array}{l}\text { Recommendation: The } \\
\text { as-built documentation } \\
\text { needs to be updated to } \\
\text { reflect this change. }\end{array}$ & $\begin{array}{l}\text { Operator } \\
\text { training }\end{array}$ \\
\hline
\end{tabular}

A plant supply temperature sensor fault, CL1, was detected when comparing the data from T-1 (plant chilled water supply temperature sensor) to the data from the five other temperature sensors in the loop. It was found that T-1 was inconsistent with the expected loop temperatures; T-1 was expected to be comparable or slightly cooler than downstream temperatures. T-1 was reading $5^{\circ} \mathrm{C}\left(9^{\circ} \mathrm{F}\right)$ warmer than the downstream temperatures. In reviewing historical data, the chilled water loop sensors did fluctuate in response to the plant and chiller availability with T-1 maintaining its offset from the others, further confirming the hypothesis.

In CL2, sensor faults were discovered for the flowmeter sensors, which detect heat content, flow rate, and temperature in both the chilled water and hot water supply loops. In this case, HVAC-Cx showed that the sensor values did not fluctuate, and reported only default values, indicative of a sensor failure.

In CL3, NIST identified a maintenance issue as a result of troubleshooting that began with operation monitoring of building data using HVAC-Cx. HVAC-Cx analysis identified that the discharge air temperatures from the AHUs were inadequate to cool the space. The data also showed that the building had been maintaining an occupied space temperature 24/7 for the past few years, causing little need for the discharge temperature to reach very low temperatures to quickly cool the space. The operators indicated that they had implemented the change from the original design intent to address occupant complaints. Furthermore, on selected site visits, it was observed that the dehumidification was inadequate and left the space feeling unpleasantly damp. O\&M staff had informed the Cx team that the chiller's 
repetitive call to operation throughout the day was necessary to meet the cooling needs of the space, even if that came at the cost of rapidly cycling of the chiller. As a result, the $\mathrm{Cx}$ team called for an inspection of the chiller and the pumps feeding the chilled water loop, including the AHU Chilled Water Valve Strainers which were found to be clogged with clay. This proved to be one of the most significant findings of the retro-Cx effort, discovered using HVAC-Cx and visual inspection by the $\mathrm{Cx}$ team.

In CL4, a control sequence implementation error was detected by the Cx team when observing the control signals being sent to the bypass valve, Valve 4, and by comparing the graph of the control signal in HVAC-Cx to the sequence of operation specified in the documentation for the system. Visual inspection confirmed that Valve 4 was obeying the commands sent to it and led the team to conclude that the issue arose from an error in programming the sequence of operation.

In CL5, another control sequence implementation fault was discovered for the chilled water return valve, Valve 1 . Valve 1 is intended to modulate in order to control the heat load on the campus loop when the system is operating in Mode 2, with the central plant cooling the building. However, at one point in the historical data the operators had placed the chiller loop into Mode 2, yet Valve 1 remained open at $100 \%$ instead of modulating. An inspection of the control sequences followed, and it was determined that the control sequence had never been programmed at the initial setup of the building. Therefore Valve 1 was always $100 \%$ open, causing the building to draw too much water from the campus loop. The facilities manager indicated that buildings downstream of the PA do not receive sufficient chilled water to meet their building cooling load and the chilled water return temperature for the central plant does not meet the $8{ }^{\circ} \mathrm{C}\left(14{ }^{\circ} \mathrm{F}\right)$ design differential for optimal performance of the central plant chiller. The effective bypass of chilled water at the PA likely exacerbated the problems.

In CL6, the valve positions observed during the pre-functional test deviated from the documentation. In this case, however, the documentation was incorrect, and the programmed sequence was correct. It was therefore recommended that the as-built documentation be updated to reflect the control sequence.

\subsubsection{Air-Handling System Findings}

Key findings from pre-functional testing of the air-handling units, listed in Table 2, can be viewed in three categories: 1) documentation errors, 2) issues with the implementation of the sequences of operation, and 3) issues with equipment performance. In most cases, HVAC-Cx provided the initial detection, either through the use of the analytics, or by providing the ability to review data. The Cx team used the graphing feature of HVAC-Cx extensively throughout the air-handling unit $\mathrm{Cx}$ process. It was clear through the graphs of supply air temperature and setpoint, as well as space temperature and setpoint, how the system responded to various states and what factors drove the system response. All findings were confirmed through physical inspection of the system. 
Table 2: Findings from Operation Monitoring of the PA Air-Handling Unit

\begin{tabular}{|c|c|c|c|c|c|}
\hline Fault \# & $\begin{array}{l}\text { Air- } \\
\text { Handler }\end{array}$ & Finding & $\begin{array}{l}\text { Detection } \\
\text { Method }\end{array}$ & $\begin{array}{l}\text { Resolution or } \\
\text { Recommendation }^{2}\end{array}$ & $\begin{array}{l}\text { Fault } \\
\text { Impact }\end{array}$ \\
\hline AH1 & ALL & $\begin{array}{l}\text { Control sequence } \\
\text { implementation fault: } \\
\text { Occupancy schedule not } \\
\text { implemented. }\end{array}$ & $\begin{array}{l}\text { Applying } \\
\text { HVAC-Cx } \\
\text { rules. }\end{array}$ & $\begin{array}{l}\text { Occupancy scheduling was } \\
\text { implemented. }\end{array}$ & $\begin{array}{l}\text { Energy } \\
\text { usage } \\
\text { Equipment } \\
\text { life } \\
\text { Occupant } \\
\text { comfort }\end{array}$ \\
\hline AH2 & $\begin{array}{l}\text { AHU 1b } \\
\text { AHU } 2 \\
\text { AHU } 3 \\
\text { AHU 4a } \\
\text { AHU 4b } \\
\text { AHU } 5 \\
\text { AHU } 6 \\
\text { AHU } 7\end{array}$ & $\begin{array}{l}\text { Documentation fault: Air } \\
\text { handlers were controlling } \\
\text { to space temperature } \\
\text { setpoint instead of supply } \\
\text { air temperature setpoint as } \\
\text { indicated in control } \\
\text { documentation. }\end{array}$ & $\begin{array}{l}\text { Analyzing } \\
\text { graphs in } \\
\text { HVAC-Cx. }\end{array}$ & $\begin{array}{l}\text { Control logic was left as is, } \\
\text { original implementation was } \\
\text { purposeful. Documentation } \\
\text { will need updating. }\end{array}$ & $\begin{array}{l}\text { Operator } \\
\text { training }\end{array}$ \\
\hline AH3 & AHU 1a & $\begin{array}{l}\text { Control logic fault: AHU } \\
\text { 1a controlled to supply air } \\
\text { setpoint but cycled and } \\
\text { often overshot target. }\end{array}$ & $\begin{array}{l}\text { Analyzing } \\
\text { graphs in } \\
\text { HVAC-Cx. }\end{array}$ & $\begin{array}{l}\text { The air handler had its } \\
\text { sequence of operation changed } \\
\text { to match the other air handlers } \\
\text { in modulating to a space } \\
\text { temperature setpoint. }\end{array}$ & $\begin{array}{l}\text { Equipment } \\
\text { life } \\
\text { Energy } \\
\text { usage }\end{array}$ \\
\hline AH4 & All & $\begin{array}{l}\text { Control logic fault: The } \\
\text { air handlers activated } \\
\text { heating valves during a } \\
\text { cooling mode if the space } \\
\text { temperature dropped } \\
0.55^{\circ} \mathrm{C}\left(1^{\circ} \mathrm{F}\right) \text { below } \\
\text { setpoint. }\end{array}$ & $\begin{array}{l}\text { Analyzing } \\
\text { graphs in } \\
\text { HVAC-Cx. }\end{array}$ & $\begin{array}{l}\text { A deadband of } 2.2^{\circ} \mathrm{C}\left(4^{\circ} \mathrm{F}\right) \\
\text { below the setpoint was } \\
\text { implemented. The heating } \\
\text { loop will also not open if the } \\
\text { outdoor air temperature is } \\
\text { greater than } 12.8^{\circ} \mathrm{C}\left(55^{\circ} \mathrm{F}\right) \text {. }\end{array}$ & $\begin{array}{l}\text { Energy } \\
\text { usage } \\
\text { Occupant } \\
\text { comfort }\end{array}$ \\
\hline AH5 & All & $\begin{array}{l}\text { Sensor fault: The values } \\
\text { for flow were reading } 1.4 \\
\mathrm{Kg} / \mathrm{s}(2500 \mathrm{CFM}) \text { when } \\
\text { the fan wasn't moving and } \\
4.2 \mathrm{Kg} / \mathrm{s}(7500 \mathrm{CFM}) \\
\text { when the maximum flow } \\
\text { rate is around } 2.8 \mathrm{Kg} / \mathrm{s} \\
(5000 \mathrm{CFM}) .\end{array}$ & $\begin{array}{l}\text { Analyzing } \\
\text { graphs in } \\
\text { HVAC-Cx. }\end{array}$ & $\begin{array}{l}\text { The calculations for flow } \\
\text { rate will need to be redone } \\
\text { on site. } \\
\text { A logical rule should be } \\
\text { implemented in HVAC-Cx } \\
\text { that checks that flow rate is } \\
\text { close to zero when the fan } \\
\text { speed is close to zero.* }\end{array}$ & \\
\hline
\end{tabular}




\begin{tabular}{|l|l|l|l|l|l|}
\hline Fault \# & $\begin{array}{l}\text { Air- } \\
\text { Handler }\end{array}$ & Finding & $\begin{array}{l}\text { Detection } \\
\text { Method }\end{array}$ & $\begin{array}{l}\text { Resolution or } \\
\text { Recommendation }{ }^{2}\end{array}$ & $\begin{array}{l}\text { Fault } \\
\text { Impact }\end{array}$ \\
\hline AH6 & $\begin{array}{l}\text { AHU 1a } \\
\text { and } \\
\text { AHU 1b }\end{array}$ & $\begin{array}{l}\text { Sensor fault: Space } \\
\text { temperatures in the } \\
\text { auditorium were not } \\
\text { meeting the setpoints. } \\
\text { Sensor locations were } \\
\text { mismatched causing } \\
\text { skewed readings. One } \\
\text { sensor was off calibration } \\
\text { by } 2.2^{\circ} \mathrm{C}\left(4^{\circ} \mathrm{F}\right) .\end{array}$ & $\begin{array}{l}\text { Analyzing } \\
\text { graphs in } \\
\text { HVAC-Cx. }\end{array}$ & $\begin{array}{l}\text { Temperature offset was } \\
\text { corrected. An average space } \\
\text { temperature value and average } \\
\text { temperature setpoint was } \\
\text { created for the Auditorium. }\end{array}$ & $\begin{array}{l}\text { Occupant } \\
\text { comfort } \\
\text { Energy } \\
\text { usage }\end{array}$ \\
\hline
\end{tabular}

* This recommendation goes to the HVAC-Cx developers but is noted here as a finding of the Cx process.

AH1 was one of the first and most significant finding because the PA has a unique occupancy profile, with long unoccupied periods, and short periods with high thermal loads due to the number of spectators, performers and lights in use. Occupancy scheduling was detailed in both the design documents and the control sequences, but it was evident through operation monitoring using HVAC-Cx that the systems were running 24 hours a day, 7 days a week, year-round. This represented a tremendous energy cost, and because the thermal loads were often small, the systems overshot and undershot setpoints, unable to maintain comfort conditions reliably.

Findings AH2 and AH3 were identified as a result of a discrepancy in the trending data compared with the documentation for the sequence of operation. The documentation states that the AHU controls its supply air temperature in response to a supply air setpoint. In practice and noted in AH2, however, all air handlers except AHU 1a were controlling their cooling coils and fans to maintain a space temperature setpoint and were tracking the space temperature. In addition, the trend data showed that when AHU 1a attempted to modulate to meet a supply air setpoint, it underwent rapid cycling of the cooling coil. A review of the programming of the controls showed that the origin of AH3 dated back to the original implementation. The discrepancy was brought to the attention of the operator and the controls company. It was determined that the changes had been purposefully made, and that AHU 1a should also have been changed. The $\mathrm{Cx}$ team determined that it was an appropriate control scheme for the building and made the recommendation to program AHU 1a in the same way as the other AHUs, and to update the documentation for all AHUs.

The finding that the air handlers would engage the heating coil in cooling modes, AH4, had one of the largest impacts on energy efficiency and occupant comfort. The team identified the error using HVAC-Cx graphs to examine the signals being sent by the air handler controllers when space temperatures dropped $0.5^{\circ} \mathrm{C}\left(1^{\circ} \mathrm{F}\right)$ below the setpoint in cooling mode. The implemented changes introduced a deadband to the space temperature to delay mode changes for the air handlers and modifying the way the heating/cooling mode was determined by locking out the heating mode when the outdoor air temperature (OAT) is greater than $12.8^{\circ} \mathrm{C}\left(55^{\circ} \mathrm{F}\right)$. Overall, the effects of these errors in the original programming were more apparent when attached to the graphic display in HVAC-Cx, which could show both small and large time scales of data versus a typical controls 
interface graphic (such as the one present at the field site) that can only show data trends over a fixed three-day period.

The AH5 sensor fault was observed in data trends during operation monitoring. The values for airflow were $4248 \mathrm{~m}^{3} / \mathrm{h}$ (2500 CFM) when the fan was switched off and read as high as $12742 \mathrm{~m}^{3} / \mathrm{h}(7500 \mathrm{CFM})$ at the maximum flowrate. A review of the fan curve indicated the maximum expected flow rate is around $8495 \mathrm{~m}^{3} / \mathrm{h}(5000 \mathrm{CFM})$. The Cx team recommended that the flow sensors be recalibrated on site.

The Cx team also inspected temperature trends from the building control system over the course of the day and compared them to the temperatures in those spaces and air handlers using a hand-held temperature sensing device. Two air handlers, AHU 1a and AHU 1b, showed anomalies. These air handlers and their respective space temperature sensors serve two halves of the auditorium space. At times, one AHU reported the room conditions were below setpoint cold and engaged heating while the other AHU reported the room was above setpoint and engaged cooling. The auditorium space temperature showed the space could not consistently maintain the setpoint, AH6. The cause was traced back to a wiring installation error for temperature sensors that served as inputs to AHU 1a and AHU 1b, which were reversed. Furthermore, the two sensors were out of calibration, with one of the sensors reading $2.2{ }^{\circ} \mathrm{C}\left(4^{\circ} \mathrm{F}\right)$ lower than the actual room conditions. The $\mathrm{Cx}$ team recommended recalibration of the sensors and implemented averaging of the two space temperature sensors to serve as inputs to the two auditorium air handlers.

\section{Active Testing}

Active testing involves both pre-functional checks and functional performance tests. Prefunctional checks are needed to ensure that all components are functional. It involves many steps that require visual inspection of systems and comparisons to system documentation. However, there is a potential for automation of some repetitive checks such as commanding dampers to open and close. Once pre-functional tests are complete, and any issues have been corrected, functional performance tests are used to evaluate how components work together following the control sequences to meet the design intent. The findings from operation monitoring and any existing performance issues identified by the O\&M staff are valuable to the $\mathrm{Cx}$ team as they develop the active testing plan to verify the full sequence of operations for the systems and to diagnose performance problems.

Prior to the team site visit, the Cx agent created an initial test plan that outlined Cx tests to be performed on the air-side and water-side systems. Test scripts were developed by NIST based on the initial test plan and industry references [18] using the scripting environment of HVAC-Cx. These test scripts were improved as more information was gathered, before the test plan was implemented. A list of HVAC-Cx active tests is found in Appendix C. Active tests were implemented during the Cx process, proving the capability of HVAC-Cx to communicate via BACnet and control the devices in the building, and to emulate the actions taken by a Cx agent. HVAC-Cx was able to succesfully perform several test commands for reading and writing data of various data types and across multiple devices. During pre-functional checks, the team inspected the physical components of the systems and observed responses to control logic commands as necessary. As faults were discovered, they were resolved through implementing changes in the control sequences, calibrating components, or other means. All actions were documented and if an issue could not be 
resolved, a recommendation was noted. During functional performance tests the system was tested in all modes of operation as described in Appendix A.

\subsection{Active Testing Results (July 2016)}

HVAC-Cx was able to successfully emulate the active tests performed by a Cx agent, which are documented in Appendix $\mathrm{C}$ of this report. Tables 3-6 list the findings from active testing of the chiller loops and nine AHUs that serve the PA. The findings in Tables 3, 5 and 6 identify the component where the issue was found, how it was found and at what point in the retro-Cx process, what action was taken to resolve the issue or what recommendation was made, and the relative impact on the system of the issue or fault on equipment life, energy usage, and/or occupant comfort.

\subsubsection{Chilled Water Distribution System Findings}

Table 3 presents the findings observed during the $\mathrm{Cx}$ of the chiller loop, with the Fault \# designation continuing sequentially from Table 1. Appendix A describes the PA chilled water system, including the modes of operation that are referenced in the chiller loop findings in Table 3.

Table 3: Findings from the Pre-functional and Active Cx Tests of the PA Chilled Water Loops

\begin{tabular}{|c|c|c|c|c|c|}
\hline $\begin{array}{l}\text { Fault } \\
\#\end{array}$ & Component & Finding & $\begin{array}{l}\text { Detection } \\
\text { Method }\end{array}$ & $\begin{array}{l}\text { Resolution or } \\
\text { Recommendation }^{2}\end{array}$ & $\begin{array}{l}\text { Fault } \\
\text { Impact }\end{array}$ \\
\hline CL7 & Chiller & $\begin{array}{l}\text { Mechanical fault: } \\
\text { The chiller had a } \\
\text { broken pressure } \\
\text { transducer and the } \\
\text { chiller does not } \\
\text { communicate with } \\
\text { the BAS. }\end{array}$ & $\begin{array}{l}\text { Pre-functional } \\
\text { testing of the } \\
\text { connection of } \\
\text { BACnet } \\
\text { objects and } \\
\text { hardware } \\
\text { components. }\end{array}$ & $\begin{array}{l}\text { The transducer has been } \\
\text { replaced. The various } \\
\text { chiller } \mathbf{I} / \mathrm{O} \text { values } \\
\text { should be connected to } \\
\text { the BAS. }\end{array}$ & $\begin{array}{l}\text { Equipment } \\
\text { life } \\
\text { Energy } \\
\text { usage }\end{array}$ \\
\hline CL8 & $\begin{array}{l}\text { Analog } \\
\text { chilled water } \\
\text { pressure } \\
\text { sensors in } \\
\text { AHUs }\end{array}$ & $\begin{array}{l}\text { Mechanical fault: } \\
\text { Several analog } \\
\text { pressure sensors } \\
\text { are misaligned or } \\
\text { broken. }\end{array}$ & $\begin{array}{l}\text { Visual } \\
\text { inspection. }\end{array}$ & $\begin{array}{l}\text { The pressure gauges } \\
\text { should be replaced. }\end{array}$ & $\begin{array}{l}\text { Operator } \\
\text { training } \\
\text { Equipment } \\
\text { life }\end{array}$ \\
\hline CL9 & $\begin{array}{l}\text { CWP-2 } \\
\text { (building } \\
\text { pump) and } \\
\text { piping }\end{array}$ & $\begin{array}{l}\text { Mechanical fault: } \\
\text { CWP-2 was out of } \\
\text { service. }\end{array}$ & $\begin{array}{l}\text { Visual } \\
\text { inspection. }\end{array}$ & $\begin{array}{l}\text { The cause of the } \\
\text { repeated valve failure } \\
\text { should be determined. } \\
\text { Once the other } \\
\text { components of the } \\
\text { chilled water } \\
\text { distribution system } \\
\text { have been fixed, this } \\
\text { valve should be } \\
\text { replaced and } \\
\text { monitored. }\end{array}$ & $\begin{array}{l}\text { Equipment } \\
\text { life } \\
\text { Energy } \\
\text { usage }\end{array}$ \\
\hline
\end{tabular}




\begin{tabular}{|c|c|c|c|c|c|}
\hline $\begin{array}{l}\text { Fault } \\
\#\end{array}$ & Component & Finding & $\begin{array}{l}\text { Detection } \\
\text { Method }\end{array}$ & $\begin{array}{l}\text { Resolution or } \\
\text { Recommendation }{ }^{2}\end{array}$ & $\begin{array}{l}\text { Fault } \\
\text { Impact }\end{array}$ \\
\hline CL10 & $\begin{array}{l}\text { V-1 Chilled } \\
\text { water bypass } \\
\text { valve }\end{array}$ & $\begin{array}{l}\text { Mechanical fault: } \\
\text { The valve was } \\
\text { stuck closed and } \\
\text { did not respond to } \\
\text { commands. }\end{array}$ & $\begin{array}{l}\text { Performing } \\
\text { pre-functional } \\
\text { testing using } \\
\text { test scripts in } \\
\text { HVAC-Cx. }\end{array}$ & $\begin{array}{l}\text { The cause of the valve } \\
\text { being stuck should be } \\
\text { determined and a } \\
\text { replacement made if } \\
\text { necessary. }\end{array}$ & $\begin{array}{l}\text { Equipment } \\
\text { life } \\
\text { Energy } \\
\text { usage }\end{array}$ \\
\hline CL11 & $\begin{array}{l}\text { CWP-1 } \\
\text { (Chiller } \\
\text { pump) } \\
\text { Chiller }\end{array}$ & $\begin{array}{l}\text { Control logic } \\
\text { fault: The pump } \\
\text { runs continuously } \\
\text { even if the chiller } \\
\text { is not being called } \\
\text { for. }\end{array}$ & $\begin{array}{l}\text { Examining } \\
\text { control logic. }\end{array}$ & $\begin{array}{l}\text { The pump should be } \\
\text { programmed to run } \\
\text { only when the chiller } \\
\text { runs and up to five } \\
\text { minutes after the } \\
\text { chiller shuts off. }\end{array}$ & $\begin{array}{l}\text { Energy } \\
\text { usage } \\
\text { Equipment } \\
\text { life }\end{array}$ \\
\hline CL12 & $\begin{array}{l}\text { AHU cooling } \\
\text { Coil } \\
\text { Strainers }\end{array}$ & $\begin{array}{l}\text { Mechanical fault: } \\
\text { The cooling coil } \\
\text { was unable to } \\
\text { reject heat to the } \\
\text { chilled water loop. }\end{array}$ & $\begin{array}{l}\text { Functional } \\
\text { Testing using } \\
\text { HVAC-Cx } \\
\text { scripts. } \\
\text { Visual } \\
\text { Inspection. }\end{array}$ & $\begin{array}{l}\text { The strainers should be } \\
\text { cleaned, and the system } \\
\text { retested. }\end{array}$ & $\begin{array}{l}\begin{array}{l}\text { Energy } \\
\text { usage }\end{array} \\
\text { Occupant } \\
\text { comfort } \\
\text { Equipment } \\
\text { life }\end{array}$ \\
\hline
\end{tabular}

The determination of the faulty pressure transducer in the chiller, CL7, came from an inspection of the rapid cycling of the chiller. The Cx team wanted to investigate its performance even though it is not connected to the BAS. An attempt to shut the chiller off and turn it back on via mode selection resulted in an alarm status being activated and the chiller becoming unresponsive. Further investigation revealed that one of the primary electrical circuits for the chiller was not working but that manually bypassing this circuit would allow the chiller to continue running. Due to the high load on the system at the time, the operator decided the best course of action was to continue to run the chiller until the manufacturer could replace the part.

During the visual inspection of the HVAC equipment, it was evident that several analog pressure sensors were misaligned or broken, with the gauge showing a reading beyond the maximum value. As these gauges are a useful tool to building operators, it was recommended that the faulty pressure gauges be replaced. Similarly, the visual inspection showed that CWP-2 was out of service. The building operators reported that this pump has failed three times since the new HVAC system was installed. Further investigation was recommended.

A faulty bypass valve, CL10, was discovered through a standard pre-functional test where the team commanded the actuator to move and observed the response. At first, the valve would only actuate to $60 \%$ open when commanded to $100 \%$. After the valve was commanded to close and actuate again, it would not open past $0 \%$. Inspecting the controls wiring led to no further clarification as everything was connected correctly. In this scenario, the finding was recorded with a recommendation of replacing the valve. 
For CL11, inspection of the chiller and the control documentation revealed that the chiller pump had no control-based connection to the actual chiller, only to the mode control logic. Therefore, it would run continuously if the chilled water loop was operating in Mode 3a, 3b, or 4 (see Appendix A). If the decision was made to keep the chiller off the BAS, a more efficient method for energy saving would be to connect the pump's operation to the chiller as well, while maintaining the ability to read its status through the BAS.

As a part of the retro-Cx process, a typical occupancy schedule was implemented using the building controls software. The $\mathrm{Cx}$ team then observed that the air handlers took several hours to cool the space in the morning following a night setback period. This revealed the extent to which the air handler cooling coils were limited, CL12. The team observed the insulation around the AHU strainer locations and noticed it appeared untouched. This was a strong indication that the insulation had never been removed to open and clean the strainers. The $\mathrm{Cx}$ agent suggested that a large blockage in the pipes could be the cause of inadequate heat exchange occurring at the AHU coils. Therefore, a recommendation was made to clean all strainers in the PA and to retest the system.

\subsubsection{Active Tests Following Strainer Cleaning}

Once the filter strainers had been cleaned of debris, the Cx team was able to perform mode switch tests as well as test the system response to heat loads. On a design day with an outside air temperature of $35^{\circ} \mathrm{C}\left(95^{\circ} \mathrm{F}\right)$, the system was able to cool the building from a nighttime setback temperature of around $24.4^{\circ} \mathrm{C}\left(76{ }^{\circ} \mathrm{F}\right)$ to a $22.2^{\circ} \mathrm{C}\left(72{ }^{\circ} \mathrm{F}\right)$ setpoint in 20 minutes. This was accomplished using Mode 3b, and demonstrated the ability to respond to a sudden heat load, but is not the most efficient way to operate the buiding continuously. The various modes were then tested to see if they could maintain a setpoint on a nonperformance day where the setpoint would only need to be $23.3^{\circ} \mathrm{C}\left(74{ }^{\circ} \mathrm{F}\right)$ to keep the occupants comfortable. Table 4 below outlines the modes and their success in maintaining setpoint and responding to heat load.

Table 4: Summary of Active Testing of the Chiller Loop

\begin{tabular}{|c|c|c|c|c|}
\hline Mode & $\begin{array}{l}\text { Maintain } \\
23.3^{\circ} \mathrm{C} \\
\left(74^{\circ} \mathrm{F}\right)\end{array}$ & $\begin{array}{l}\text { Cool space } \\
\text { to } 20^{\circ} \mathrm{C} \\
\left(68^{\circ} \mathrm{F}\right)\end{array}$ & $\begin{array}{l}\text { Maintain } 20^{\circ} \mathrm{C} \\
\left(68^{\circ} \mathrm{F}\right) \text { during } \\
\text { performance }\end{array}$ & Comment \\
\hline Mode 2a & Yes & No & No & $\begin{array}{l}\text { Could potentially be a default mode for } \\
\text { when space is occupied but no } \\
\text { performance is scheduled that day. }\end{array}$ \\
\hline Mode 2b & Yes & No & No & $\begin{array}{l}\text { Activating the building pump got the } \\
\text { space temperatures closer to } 20^{\circ} \mathrm{C} \\
\left(68^{\circ} \mathrm{F}\right) \text { but the flow would choke as } \\
\mathrm{V}-1 \text { closed to maintain the } 8.3^{\circ} \mathrm{C} \\
\left(15^{\circ} \mathrm{F}\right) \text { max temperature drop across } \\
\text { the building. }\end{array}$ \\
\hline $\begin{array}{l}\text { Mode 3b (with } \\
\text { chiller offline) }\end{array}$ & Yes & Yes & No & $\begin{array}{l}\text { Cooled the space to } 20^{\circ} \mathrm{C}\left(68^{\circ} \mathrm{F}\right) \text { in } \\
1 \mathrm{~h} \text {, could likely not maintain if a high } \\
\text { heat load was in the building, would } \\
\text { likely need to bring the chiller online. }\end{array}$ \\
\hline
\end{tabular}




\begin{tabular}{|c|c|c|c|c|}
\hline Mode & $\begin{array}{l}\text { Maintain } \\
23.3^{\circ} \mathrm{C} \\
\left(74^{\circ} \mathrm{F}\right)\end{array}$ & $\begin{array}{l}\text { Cool space } \\
\text { to } 20^{\circ} \mathrm{C} \\
\left(68^{\circ} \mathrm{F}\right)\end{array}$ & $\begin{array}{l}\text { Maintain } 20^{\circ} \mathrm{C} \\
\left(68^{\circ} \mathrm{F}\right) \text { during } \\
\text { performance }\end{array}$ & Comment \\
\hline $\begin{array}{l}\text { Mode } 3 \mathrm{~b} \\
\text { (chiller on if } \\
\text { necessary, } \\
\text { setpoint at } \\
6.7^{\circ} \mathrm{C}\left(44^{\circ} \mathrm{F}\right) \text { ) }\end{array}$ & Yes & Yes & Yes & $\begin{array}{l}\text { By placing the local chiller setpoint at } \\
6.7^{\circ} \mathrm{C}\left(44^{\circ} \mathrm{F}\right) \text {, the plant chilled water } \\
\text { system would take precendence in } \\
\text { meeting building demand and the local } \\
\text { chiller would only come online if the } \\
\text { loads were too great. }\end{array}$ \\
\hline Mode 4 & Yes & Yes & Unknown & $\begin{array}{l}\text { The building was able to maintain } \\
20^{\circ} \mathrm{C}\left(68^{\circ} \mathrm{F}\right) \text { as the discharge } \\
\text { temperatures were able to get very low } \\
\text { in the air handlers and could potentially } \\
\text { maintain the space temperature in a } \\
\text { performance. This would need to be } \\
\text { tested. }\end{array}$ \\
\hline
\end{tabular}

\subsubsection{Air-Handling System Findings}

Table 5 describes the findings observed and resolved during the $\mathrm{Cx}$ of the air-handling system, with the Fault \# designation continuing from Table 2. Appendix B describes the PA air-handling system.

Table 5: Findings from Pre-functional and Active Testing of the PA AHUs

\begin{tabular}{|l|l|l|l|l|l|}
\hline $\begin{array}{l}\text { Fault } \\
\#\end{array}$ & $\begin{array}{l}\text { Air- } \\
\text { Handler }\end{array}$ & Finding & $\begin{array}{l}\text { Detection } \\
\text { Method }\end{array}$ & $\begin{array}{l}\text { Resolution or } \\
\text { Recommendation }\end{array}$ & Fault Impact \\
\hline AH7 & All & $\begin{array}{l}\text { Control sequence } \\
\text { implementation fault: The } \\
\text { air handlers were } \\
\text { programmed with a 24/7 } \\
\text { occupancy schedule. }\end{array}$ & $\begin{array}{l}\text { Examining } \\
\text { BACnet values } \\
\text { for occupancy } \\
\text { during pre- } \\
\text { functional } \\
\text { testing. }\end{array}$ & $\begin{array}{l}\text { Remove override } \\
\text { commands and } \\
\text { implement occupancy } \\
\text { schedule. }\end{array}$ & $\begin{array}{l}\text { Equipment } \\
\text { life }\end{array}$ \\
\hline AH8 & All & $\begin{array}{l}\text { Sensor fault: The } \\
\text { humidity sensor reported a } \\
\text { constant 100 \% relative } \\
\text { humidity. }\end{array}$ & $\begin{array}{l}\text { Examining } \\
\text { BACnet values } \\
\text { during pre- } \\
\text { functional } \\
\text { testing. }\end{array}$ & $\begin{array}{l}\text { The sensor was reset } \\
\text { and started recording } \\
\text { correctly. }\end{array}$ & $\begin{array}{l}\text { Operator } \\
\text { training }\end{array}$ \\
\hline AH9 & $\begin{array}{l}\text { AHU 4b } \\
\text { (Lobby) }\end{array}$ & $\begin{array}{l}\text { Mechanical fault: The } \\
\text { outdoor air damper could } \\
\text { not stroke fully open and } \\
\text { its minimum flow was } \\
\text { inadequate. }\end{array}$ & $\begin{array}{l}\text { Performing Cx } \\
\text { tests via the } \\
\text { control system } \\
\text { graphical } \\
\text { interface. }\end{array}$ & $\begin{array}{l}\text { The balancing of the } \\
\text { damper should be } \\
\text { checked to see if it can } \\
\text { move to its correct } \\
\text { positions when } \\
\text { commanded. If not, a } \\
\text { replacement is } \\
\text { recommended. }\end{array}$ & $\begin{array}{l}\text { Equipment } \\
\text { life }\end{array}$ \\
\hline
\end{tabular}




\begin{tabular}{|c|c|c|c|c|c|}
\hline $\begin{array}{l}\text { Fault } \\
\#\end{array}$ & $\begin{array}{l}\text { Air- } \\
\text { Handler }\end{array}$ & Finding & $\begin{array}{l}\text { Detection } \\
\text { Method }\end{array}$ & $\begin{array}{l}\text { Resolution or } \\
\text { Recommendation }^{2}\end{array}$ & Fault Impact \\
\hline AH10 & All & $\begin{array}{l}\text { Control logic fault: The } \\
\text { air handlers currently have } \\
\text { a maximum outdoor air } \\
\text { damper allowance of } \\
50 \% \text {. }\end{array}$ & $\begin{array}{l}\text { Visual } \\
\text { Inspection. }\end{array}$ & $\begin{array}{l}\text { It is recommended } \\
\text { that this be increased } \\
\text { to allow for a full } \\
\text { stroke range. }\end{array}$ & Energy usage \\
\hline AH11 & All & $\begin{array}{l}\text { Documentation and } \\
\text { Control sequence } \\
\text { implementation faults: } \\
\text { Exhaust dampers } \\
\text { described in } \\
\text { documentation aren't } \\
\text { connected to the BAS. }\end{array}$ & $\begin{array}{l}\text { Visual } \\
\text { Inspection. }\end{array}$ & $\begin{array}{l}\text { It is recommended } \\
\text { that Variable } \\
\text { Frequency Drives } \\
\text { (VFDs) connected to } \\
\text { the BAS be installed } \\
\text { on these exhaust } \\
\text { dampers to allow for } \\
\mathrm{CO}_{2} \text { control and } \\
\text { economizing. }\end{array}$ & Energy usage \\
\hline AH12 & $\begin{array}{l}\text { AHU 4a } \\
\text { (Lobby) } \\
\text { AHU 4b } \\
\text { (Lobby) }\end{array}$ & $\begin{array}{l}\text { Sensor fault: Lobby space } \\
\text { was too cold. Sensor } \\
\text { locations were } \\
\text { mismatched causing a } \\
\text { mismatched AHU } \\
\text { response. One sensor was } \\
\text { off calibration, with the } \\
\text { space temp sensors } \\
\text { reading } 1.7^{\circ} \mathrm{C}\left(3^{\circ} \mathrm{F}\right) \text { too } \\
\text { high. }\end{array}$ & $\begin{array}{l}\text { Performing pre- } \\
\text { functional } \\
\text { testing. }\end{array}$ & $\begin{array}{l}\text { The sensors were } \\
\text { recalibrated to read the } \\
\text { correct temperature. }\end{array}$ & $\begin{array}{l}\text { Energy usage } \\
\text { Occupant } \\
\text { comfort }\end{array}$ \\
\hline AH13 & $\begin{array}{l}\text { AHU 4a } \\
\text { (Lobby) }\end{array}$ & $\begin{array}{l}\text { Mechanical fault: The } \\
\text { heating valve was found } \\
\text { to be stuck at } 40 \% \text { open, } \\
\text { though the BAS reports } \\
\text { that the valve is closed. }\end{array}$ & $\begin{array}{l}\text { Performing pre- } \\
\text { functional } \\
\text { testing on } \\
\text { components. }\end{array}$ & $\begin{array}{l}\text { The actuator should } \\
\text { be either rebalanced } \\
\text { or replaced. }\end{array}$ & $\begin{array}{l}\text { Energy usage } \\
\text { Occupant } \\
\text { comfort }\end{array}$ \\
\hline AH14 & $\begin{array}{l}\text { AHU 4a } \\
\text { (Lobby) } \\
\text { AHU 4b } \\
\text { (Lobby) }\end{array}$ & $\begin{array}{l}\text { Control logic fault: The } \\
\text { space temperature } \\
\text { readings were switched } \\
\text { for the respective sides of } \\
\text { the room. }\end{array}$ & $\begin{array}{l}\text { Performing pre- } \\
\text { functional } \\
\text { testing on } \\
\text { components. }\end{array}$ & $\begin{array}{l}\text { An average space } \\
\text { temperature value and } \\
\text { average temperature } \\
\text { setpoint was created for } \\
\text { the Lobby. }\end{array}$ & $\begin{array}{l}\text { Operator } \\
\text { Training }\end{array}$ \\
\hline AH15 & $\begin{array}{l}\text { AHU 4a } \\
\text { (Lobby) }\end{array}$ & $\begin{array}{l}\text { Mechanical fault: The air } \\
\text { filter was not flush with } \\
\text { the duct access door, } \\
\text { allowing air to bypass the } \\
\text { filter. }\end{array}$ & $\begin{array}{l}\text { Performing pre- } \\
\text { functional } \\
\text { testing on } \\
\text { components. }\end{array}$ & $\begin{array}{l}\text { The filter should be } \\
\text { adjusted or replaced } \\
\text { with a better fitting } \\
\text { filter. }\end{array}$ & $\begin{array}{l}\text { Occupant } \\
\text { comfort }\end{array}$ \\
\hline
\end{tabular}




\begin{tabular}{|c|c|c|c|c|c|}
\hline Fault & $\begin{array}{l}\text { Air- } \\
\text { Handler }\end{array}$ & Finding & $\begin{array}{l}\text { Detection } \\
\text { Method }\end{array}$ & $\begin{array}{l}\text { Resolution or } \\
\text { Recommendation }\end{array}$ & Fault Impact \\
\hline AH16 & $\begin{array}{l}\text { AHU } 2 \\
\text { (Green } \\
\text { room) }\end{array}$ & $\begin{array}{l}\text { Maintenance fault: The } \\
\text { filter is partially blocked } \\
\text { with debris. The small } \\
\text { mechanical room that } \\
\text { serves as a mixing box for } \\
\text { the return air before it } \\
\text { enters the air handler is } \\
\text { also very dirty. }\end{array}$ & $\begin{array}{l}\text { Performing pre- } \\
\text { functional } \\
\text { testing on } \\
\text { components. }\end{array}$ & $\begin{array}{l}\text { The filter needs to be } \\
\text { replaced and the } \\
\text { room needs to be } \\
\text { cleaned. }\end{array}$ & $\begin{array}{l}\text { Occupant } \\
\text { comfort }\end{array}$ \\
\hline AH17 & All & $\begin{array}{l}\text { Control logic fault: } \\
\text { During night setback } \\
\text { mode, a low space } \\
\text { temperature was } \\
\text { simulated and yet the } \\
\text { heating did not trigger. }\end{array}$ & $\begin{array}{l}\text { Performing } \\
\text { functional } \\
\text { performance } \\
\text { testing and } \\
\text { checking the } \\
\text { control } \\
\text { sequences. }\end{array}$ & $\begin{array}{l}\text { The control sequences } \\
\text { were changed to } \\
\text { remove contradictory } \\
\text { checks and allow for } \\
\text { setback control. }\end{array}$ & $\begin{array}{l}\text { Occupant } \\
\text { comfort }\end{array}$ \\
\hline AH18 & All & $\begin{array}{l}\text { Control sequence } \\
\text { implementation fault: } \\
\text { There was no control } \\
\text { sequence programmed to } \\
\text { close the outdoor air } \\
\text { damper if the mixed air } \\
\text { temperature dropped } \\
\text { below a } 7.2^{\circ} \mathrm{C}\left(45^{\circ} \mathrm{F}\right) \\
\text { setpoint. }\end{array}$ & $\begin{array}{l}\text { Pre-functional } \\
\text { checks } \\
\text { comparing } \\
\text { implemented } \\
\text { control } \\
\text { sequences with } \\
\text { documented } \\
\text { sequences. }\end{array}$ & $\begin{array}{l}\text { The sequence was } \\
\text { added to close the } \\
\text { outdoor air damper to } \\
10 \% \text { to meet minimum } \\
\text { outdoor air. It is } \\
\text { recommended that it } \\
\text { close to protect coils. }\end{array}$ & $\begin{array}{l}\text { Equipment } \\
\text { life }\end{array}$ \\
\hline AH19 & All & $\begin{array}{l}\text { Control logic fault: } 10 \% \\
\text { outdoor air damper } \\
\text { position may be } \\
\text { inadequate for large air } \\
\text { handlers and too much for } \\
\text { small ones. }\end{array}$ & $\begin{array}{l}\text { Examining the } \\
\text { system } \\
\text { documentation. }\end{array}$ & $\begin{array}{l}\text { Calculations should } \\
\text { be done to determine } \\
\text { the proper air intake } \\
\text { and corresponding } \\
\text { outdoor air damper } \\
\text { position. }\end{array}$ & \\
\hline AH20 & All & $\begin{array}{l}\text { Control logic fault: The } \\
\text { current economizer } \\
\text { control sequence does not } \\
\text { allow for true free } \\
\text { cooling. }\end{array}$ & $\begin{array}{l}\text { Pre-functional } \\
\text { checks } \\
\text { comparing } \\
\text { implemented } \\
\text { control } \\
\text { sequences with } \\
\text { documented } \\
\text { sequences. }\end{array}$ & $\begin{array}{l}\text { It is recommended } \\
\text { that a gradation of } \\
\text { free cooling, assisted, } \\
\text { and fully mechanical } \\
\text { cooling be } \\
\text { implemented. }\end{array}$ & Energy usage \\
\hline
\end{tabular}

A major finding from the active testing process was the lack of occupancy-based control. Fault AH7 was found originally through examining the occupancy data point on the BAS and confirming the constant operation of the components visually. Inquiring with the auditorium staff revealed that on performance days, the system needed to run non-stop in all areas of the building, otherwise it could not reach a comfortable temperature quickly 
enough. It was evident that at one point, a manual override of the occupancy schedule caused the status to change to occuppied around-the-clock for all air handlers and the system was never returned to its intended occupancy schedule. Aside from the chilled water loop blockage, which is likely the root cause of the occupancy schedule change, this was the most impactful finding at the PA.

Additional findings from the active testing process were found by stepping through comissioning tests that involved invoking commands using HVAC-Cx or using the control system interface, and obseving the response in person. The components were also visually inspected for faults. Replacements and recalibrations were carried out when possible or documented as a recommendation.

In examining the sensor readings as part of the pre-functional testing, a sensor fault, AH8 was noted as the humidity sensor was reporting a constant relative humidity of $100 \%$. The sensor was reset and began detecting the correct values. AH9 was found when performing a pre-functional test calling for a full stroke of the damper. The visual-inspection test showed that the outdoor air damper could not stroke fully open, and the minimum flow position was fully closed and therefore did not provide adequate outdoor air. Rebalancing of the dampers was recommended. Subsequently, while observing the BACnet objects, it was determined that all air-handling units with outdoor air intakes have a maximum damper position allowance of $50 \%$, AH10. It was recommended that this restriction be removed to allow for use of free cooling. Another finding from pre-functional testing was AH11 which showed that the exhaust dampers described in the documentation to be programmed to aid in economizing and $\mathrm{CO}_{2}$ control were never connected to the BAS. As a result, energy usage was higher because economizing was less effective. Occupant comfort was also reduced as building pressurization was not managed and resulting in periods when the building was underpressurized making it difficult to open doors, or over pressurized leading to excessive air leakage.

Other comfort complaints originated from the lobby space. Building operators reported that the AHUs were unable to respond to load changes during performances and as a result the space was maintained at a low setpoint. An office space adjacent to the lobby that is also served by AHU 4b was reported by the occupants as too cold; they used small electric space heaters in summer. Several issues were found to contribute to these comfort complaints. The two lobby space temperature sensors were out of calibration, with one of the sensors reading $1.7^{\circ} \mathrm{C}\left(3^{\circ} \mathrm{F}\right)$ higher than the actual room conditions, AH12. As part of the pre-functional tests of all AHUs, the Cx team found that the hot water valve was stuck at $40 \%$ open even though the BAS reported that the valve was closed, AH13. The Cx team recommended rebalancing the valves to ensure the valve responded to commands, or to replace the faulty valve. It was also found that the space temperature readings for the two sides of the lobby were reversed, AH14. The Cx team recommended recalibration of the sensors and implemented averaging of the two space temperature sensors to serve as inputs to the two lobby air handlers. Another finding was that the air filter was not flush with the duct access door, allowing air, dust, and debris to bypass the filter, AH15. The Cx team recommended that the actuator controlling the hot water valve serving AHU 4a be fixed or replaced, and that the filter framing be modified to reduce air bypass or that the correct size filter be installed. 
One maintenance fault, AH16, was identified in the pre-functional testing. This fault concerned the poor state of the mechanical room housing AHU2 and serving as the mixing box for the return air that is drawn into the air handler. There was a lot of dirt, debris and refuse present, including debris that partially blocked the intake filter. It was recommended that the room be cleaned.

Two of the findings, AH17 and AH18, were related to the controls programming for the air handlers. In these cases, the team used automated test scripts to command an AHU into a nighttime setback mode, where the system should respond if it receives a signal indicating that the temperature has dropped below the nighttime low setpoint of $7.2^{\circ} \mathrm{C}\left(45^{\circ} \mathrm{F}\right)$. The system did not close the outdoor air damper or engage the heating coil, both of which are faults that could risk freezing the cooling coil and potentially disabling the air handler. The $\mathrm{Cx}$ team compared the implemented control sequences with the control sequence documentation and found that the control sequence to close the outdoor air damper if the mixed air temperature dropped below a $7.2^{\circ} \mathrm{C}\left(45^{\circ} \mathrm{F}\right)$ setpoint was not implemented. The control sequences were changed to correct this.

AH19 and AH20 are faults relating to the efficient operation of the air handlers. There is no operational economizer mode due to the fact that there is no controllable exhaust system to enable controlled intake of outdoor air in the system. Once this is addressed, an appropriate economizer control sequence can be implemented.

Overall, HVAC-Cx was able to meet its intended purpose for operation monitoring as well as supporting active testing by performing $\mathrm{Cx}$ tests that required signals be sent to the various components

\subsubsection{Miscellaneous Findings}

During the course of operation monitoring, pre-functional testing and functional performance testing of the chilled water loops and air-handling units, several additional findings were made related to other building systems, including hot water loops, outdoor lighting, and access doors. These findings are noted in Table 6.

Table 6: Miscellaneous Findings

\begin{tabular}{|c|c|c|c|c|}
\hline Component & Finding & $\begin{array}{l}\text { Detection } \\
\text { Method }\end{array}$ & $\begin{array}{l}\text { Resolution or } \\
\text { Recommendation }^{2}\end{array}$ & $\begin{array}{l}\text { Fault } \\
\text { Impact }\end{array}$ \\
\hline $\begin{array}{l}\text { HW Loop } \\
\text { Valve } 1 \\
\text { (loop exit } \\
\text { valve) }\end{array}$ & $\begin{array}{l}\text { Mechanical fault: Valve } 1 \text { is } \\
\text { controlled to be closed and } \\
\text { locked out during cooling } \\
\text { season as an energy-saving } \\
\text { measure, yet the AHUs are } \\
\text { receiving hot water when there } \\
\text { is a call for heating, rather than } \\
\text { waiting for the thermal } \\
\text { dynamics of the room. }\end{array}$ & $\begin{array}{l}\text { Operation } \\
\text { monitoring } \\
\text { analysis in } \\
\text { HVAC-Cx } \\
\text { and on-site } \\
\text { pre- } \\
\text { functional } \\
\text { testing. }\end{array}$ & $\begin{array}{l}\text { The actual position of } \\
\text { the valve should be } \\
\text { determined, and its } \\
\text { actuator be } \\
\text { recalibrated or } \\
\text { replaced. }\end{array}$ & $\begin{array}{l}\text { Energy } \\
\text { usage } \\
\text { Occupant } \\
\text { comfort } \\
\text { Equipment } \\
\text { life }\end{array}$ \\
\hline $\begin{array}{l}\text { Auditorium } \\
\text { lighting }\end{array}$ & $\begin{array}{l}\text { Control logic fault: The lights } \\
\text { were left on when the space } \\
\text { was not in use. }\end{array}$ & $\begin{array}{l}\text { Visual } \\
\text { Inspection. }\end{array}$ & $\begin{array}{l}\text { The lights were set to } \\
\text { remain off unless turned } \\
\text { on for a performance. }\end{array}$ & $\begin{array}{l}\text { Energy } \\
\text { usage } \\
\text { Equipment } \\
\text { life }\end{array}$ \\
\hline
\end{tabular}




\begin{tabular}{|c|c|c|c|c|}
\hline Component & Finding & $\begin{array}{l}\text { Detection } \\
\text { Method }\end{array}$ & $\begin{array}{l}\text { Resolution or } \\
\text { Recommendation }{ }^{2}\end{array}$ & $\begin{array}{l}\text { Fault } \\
\text { Impact }\end{array}$ \\
\hline $\begin{array}{l}\text { Outdoor } \\
\text { lighting }\end{array}$ & $\begin{array}{l}\text { Control logic fault: The LEDs } \\
\text { that illuminate the columns } \\
\text { outside of the building were on } \\
\text { during the day. }\end{array}$ & $\begin{array}{l}\text { Visual } \\
\text { Inspection. }\end{array}$ & $\begin{array}{l}\text { These should be } \\
\text { controlled by a timer. }\end{array}$ & $\begin{array}{l}\text { Energy } \\
\text { usage } \\
\text { Equipment } \\
\text { life }\end{array}$ \\
\hline $\begin{array}{l}\text { Shop roll- } \\
\text { up door }\end{array}$ & $\begin{array}{l}\text { Control sequence } \\
\text { implementation fault: The roll- } \\
\text { up door was found open for } \\
\text { several hours, letting large } \\
\text { amounts of cool air escape } \\
\text { from the conditioned shop } \\
\text { space. There is currently not a } \\
\text { door sensor connected to the } \\
\text { BAS. }\end{array}$ & $\begin{array}{l}\text { Visual } \\
\text { Inspection. }\end{array}$ & $\begin{array}{l}\text { It is recommended that } \\
\text { a door sensor be } \\
\text { connected to the BAS } \\
\text { and commanded to } \\
\text { close if the building is } \\
\text { unoccupied and it was } \\
\text { left open. }\end{array}$ & $\begin{array}{l}\text { Energy } \\
\text { usage }\end{array}$ \\
\hline $\begin{array}{l}\text { HW Loop } \\
\text { VFD bypass } \\
\text { valve }\end{array}$ & $\begin{array}{l}\text { Mechanical fault: The valve is } \\
\text { currently stuck at closed and is } \\
\text { not responding to commands to } \\
\text { actuate. }\end{array}$ & $\begin{array}{l}\text { Performing } \\
\text { pre- } \\
\text { functional } \\
\text { testing. }\end{array}$ & $\begin{array}{l}\text { The cause of the valves } \\
\text { being stuck should be } \\
\text { determined and a } \\
\text { replacement made if } \\
\text { necessary. }\end{array}$ & $\begin{array}{l}\text { Equipment } \\
\text { life }\end{array}$ \\
\hline
\end{tabular}

\section{Lessons Learned for HVAC-Cx and Next Steps}

The evaluation of HVAC-Cx performance in the field has provided valuable information to improve its future performance. HVAC-Cx was an integral tool for $\mathrm{Cx}$ of the PA and has a large potential for expanded use after key improvements of its features. Some key observations of the HVAC-Cx's diagnostic capability are:

1. The system parameters indicating the scaling for the dampers and valves are currently hardcoded to be range of zero to one. In field application, some of the outputs reported by the BAS were in the range of zero to 100 . This was resolved by re-scaling that data, but the capability of changing the range of individual parameters via the graphical user interface should be added.

2. The capacity for data analytics is currently limited by the amount of data that can be examined by a user at one time. The capabilities of the system to present data from one component for multiple months, or to present data from different components for the same month in a side-by-side comparison, would be invaluable.

3. HVAC-Cx can emulate the tests performed by a Cx agent and thereby can provide very useful information to a user, including building operators and $\mathrm{Cx}$ agents who may need to test dozens of AHUs in a systematic and repeatable manner.

4. The field application of HVAC-Cx was valuable in identifying improvements that can be made to increase its efficacy and ease-of-use.

A list of improvements includes the following updates planned for HVAC-Cx: 
1. Streamlining the test script generation process by including the ability to implement if/then logical statements as well as command statements, the ability to easily manipulate the order of commands, and the ability to quickly implement the same script for a different component.

2. Presenting the data in a more useful manner, such as the ability to present relevant pass/fail data directly to the user through data files and summary plots created by HVAC-Cx .

3. Because operators need both the knowledge of system faults and tools to prioritize their responses, it would be valuable to develop a fault rating system suitable for use in the HVAC-Cx tool that would identify faults having the greatest impact, based on the priorities of the owner (e.g., cumulative cost, energy, indoor environmental quality).

\section{Summary}

This report describes the evaluation of the use of HVAC-Cx for traditional energy retro-Cx of the Performing Arts Center at Montgomery College in Rockville, Maryland. HVAC-Cx is a publicly-available software tool that can automate some of the labor-intensive portions of pre-functional testing and functional performance testing. HVAC-Cx was validated in a laboratory environment prior to its field trial for the monitoring of chiller loops and AHUs.

The project involved a collaboration between the owner, Cx agent, and researchers who developed HVAC-Cx. Automated tests were developed for the chilled water loops and AHUs, based on tests established by the Cx agent. The application of HVAC-Cx was successful in finding a variety of faults including: 1) issues with equipment performance, and 2) issues with the implementation of the sequences of operation, and the results were verified in the field. The owners are planning to implement all recommendations. Future work will include repeating the automated tests post implementation and quantifying the costs and benefits of those actions.

In general, the potential for $\mathrm{Cx}$ agents and building operators to reduce costs by integrating automated tools is significant and increases the number systems that can be evaluated compared to a manual approach. Once the library of test scripts and the pass/fail criteria have been developed, the software tool will further simplify the process of conducting repeat testing, which can help prolong the benefits.

\section{Acknowledgments}

This field study would not have been possible without those individuals who assisted with the data collection, field validation, and Cx. Thanks are due to Steven D. Airing, James N. Gillis, and Maria Cristina Manfre of Montgomery College in Rockville, MD; Ross Wood and Andrew Distabile of Pritchett Controls in Beltsville, MD.

\section{References}

[1] ASHRAE. 2013. ASHRAE Standard 202-2013--"Commissioning Process for Buildings and Systems."

[2] Frank, M., Friedman, H., and Heinemeier, K., Toole, C., Claridge, D., Castro, N., and Haves, P. 2007. "State-of-the-Art Review for Commissioning Low Energy Buildings: Existing Cost/Benefit and Persistence Methodologies and Data, State 
of Development of Automated Tools and Assessment of Needs for Commissioning ZEB” NIST Interagency/Internal Report (NISTIR) 7356.

[3] Effinger, J., Friedman, H., and Moser, D. 2009. "A Study on Energy Savings and Measure Cost Effectiveness of Existing Building Commissioning.” Prepared for U.S. Department of Energy. http://resources.cacx.org/library/HoldingDetail.aspx?id=508.

[4] Friedman, H., Frank, M., Heinemeier, K., Crossman, K., Crowe, E., Claridge, D., Toole, C., Choinière, D., and Milesi Ferretti, N. 2012. "IEA Annex 47: CostEffective Commissioning for Existing and Low Energy Buildings.” NIST Technical Note (NIST TN) 1727. http://dx.doi.org/10.6028/NIST.TN.1727

[5] Mills, E. 2009. "Building Commissioning: A Golden Opportunity for Reducing Energy Costs and Greenhouse Gas Emissions.” http://cx.lbl.gov/2009assessment.html.

[6] Winters, D. 2014. “The Economic Benefits of Building Commissioning” U.S. Green Building Council, Green Building Information Gateway. posted April 7. http://insight.gbig.org/the-economic-benefits-of-building-commissioning/

[7] ASHRAE. 2015. ASHRAE Guideline 0.2-2015 "Commissioning Process for Existing Systems and Assemblies."

[8] Milesi Ferretti, N., Shipley, D., Zalis, W., and Bushby, S.T. 2014. "Roadmap for Building Commissioning Research Workshop Summary Report”. NIST Technical Note (NIST TN) 1849. http://dx.doi.org/10.6028/NIST.TN.1849

[9] Neumann. C. et al. 2012. “Annex 47 Report 2: Commissioning Tools for Existing and Low Energy Buildings”, NIST Technical Note (NIST TN)1744. http://dx.doi.org/10.6028/NIST.TN.1744

[10] HVAC-Cx (Version 2) [software], National Institute of Standards and Technology, and the Centre Scientifique et Technique du Bâtiment (Scientific and Technical Center for Building). 2014. https://www.nist.gov/servicesresources/software/hvac-cx-building-hvac-systems-commissioning-tool

[11] Galler, M.A. and N. Milesi Ferretti. 2017. Users Guide to HVAC-Cx v2.2. NIST Technical Note (NIST TN) 1981. https://doi.org/10.6028/NIST.TN.1981

[12] Bushby, S.T., Galler, M.A., Milesi Ferretti, N.S., and Park, C. 2010. "The Virtual Cybernetic Building Testbed - A Building Emulator", ASHRAE Transactions Vol. 116 Pt. 1.

[13] Milesi Ferretti, N.S., Galler, M.A., Bushby, S.T., and Choinière, D. 2015. "Evaluating the Performance of Diagnostic Agent for Building Operation (DABO) and HVAC-Cx Tools Using the Virtual Cybernetic Building Testbed, Science and Technology for the Built Environment, 21:8, 1154-1164, DOI: 10.1080/23744731.2015.1077670

[14] Milesi Ferretti, N.S., Galler, M.A., Bushby, S.T. 2016. Evaluating the Initial Field Performance of HVAC-Cx for Air-Handling Units. NIST Technical Note (NIST TN) 1924. http://dx.doi.org/10.6028/NIST.TN.1924 
[15] Milesi Ferretti, N.S., Galler, M.A., Bushby, S.T. 2017. "Performance Monitoring of Chilled Water Distribution Systems Using HVAC-Cx,” ASHRAE Transactions, Vol 123, Pt. 2.

[16] Greenman-Pedersen, 2008. “As-Built documentation for Parilla Performing Arts Center Mechanical and Electrical Systems Replacement Project”. Issue 3, CDD2, 05/07/08.)

[17] Pritchett Controls. 2008. “As-Built documentation for Reliable Controls BACnet Series Automatic Temperature Controls Energy Management System”. Version 12/03/2008.

[18] Portland Energy Conservation, Inc. 2006. “Functional Testing Guide for Air Handling Units”.

http://www.ftguide.org/ftg/SystemModules/AirHandlers/Functional_Testing_for _Air_Handlers.htm 


\section{Appendix A: PA Chilled Water System Description}

The Rockville Campus Central Plant provides chilled water to the PA. Chilled water is generally available May to September in a temperature range of $3.3^{\circ} \mathrm{C}$ to $5^{\circ} \mathrm{C}\left(38^{\circ} \mathrm{F}\right.$ to $\left.41^{\circ} \mathrm{F}\right)$ with a temperature differential of $8.3^{\circ} \mathrm{C}\left(15^{\circ} \mathrm{F}\right)$ across the building inlet and outlet. The chilled water central plant makes ice at night and melts it from noon to 8 p.m. to supplement the central plant chiller. Figure A-1 shows the schematic diagram of the chilled water loop for the PA building, with connections to and from the central plant shown on the left side. A dedicated, 105 ton (371 kW), air-cooled chiller ("NEW CHILLER") is available to supplement additional cooling loads. When the air-cooled chiller receives a call for cooling, it will maintain the discharge setpoint selected by the building operator in the range of $3.3^{\circ} \mathrm{C}$ to $7.2^{\circ} \mathrm{C}\left(38^{\circ} \mathrm{F}\right.$ to $\left.45^{\circ} \mathrm{F}\right)$. In its current state, this setpoint is at $6.7^{\circ} \mathrm{C}$ $\left(44^{\circ} \mathrm{F}\right)$. The chilled water pump (CWP-1) activates in modes where the air-cooled chiller is enabled through the mode control sequence. The building pump system is controlled to operate one building pump (CWP-2 or CWP-3), and a bypass valve (V-5).

The chilled water control sequence is as follows. A BACnet object exists for each of the operating modes and one mode is selected at a time via an operator control interface. Table A-1 lists the six possible modes of operation and the corresponding valve and pump sequence.

- Mode 1: the system is off.

- Mode 2 (a and b): the central plant cools the building and the air-cooled chiller is off. This mode is intended as the normal operating mode to leverage the more efficient central plant chiller capabilities.

- Mode 3 (a and b): the air-cooled chiller both cools the building and feeds the campus chilled water distribution loop. This mode is intended for use when the central plant is producing ice and the air-cooled chiller can provide supplemental cooling to the campus loop.

- Mode 4: the air-cooled chiller exclusively cools the building. This last mode is intended for use when there is no access to the plant loop, and there is limited load in the building that can be directly met by the air-cooled chiller.

Table A-1: Valve and Pump Sequencing for Chilled Water from PA Control System (Pritchett Controls, 2008).

\begin{tabular}{|c|c|c|c|c|c|c|c|}
\hline Mode & $\mathbf{V}-\mathbf{1}$ & $\mathbf{V}-\mathbf{2}$ & $\mathbf{V}-\mathbf{3}$ & $\mathbf{V}-\mathbf{4}$ & $\mathbf{V}-\mathbf{5}$ & $\begin{array}{c}\text { Chiller } \\
\text { Pump }\end{array}$ & $\begin{array}{c}\text { Building } \\
\text { Pump }\end{array}$ \\
\hline 1 & Closed & Closed & Closed & Closed & Closed & Off & Off \\
\hline 2a & Modulates & Closed & Closed & Closed & Open & Off & Off \\
\hline 2b & Modulates & Closed & Closed & Open & Closed & Off & On \\
\hline 3a & Open & Open & Closed & Closed & Open & On & Off \\
\hline 3b & Open & Open & Closed & Open & Closed & On & On \\
\hline 4 & Closed & Closed & Open & Open & Closed & On & On \\
\hline
\end{tabular}




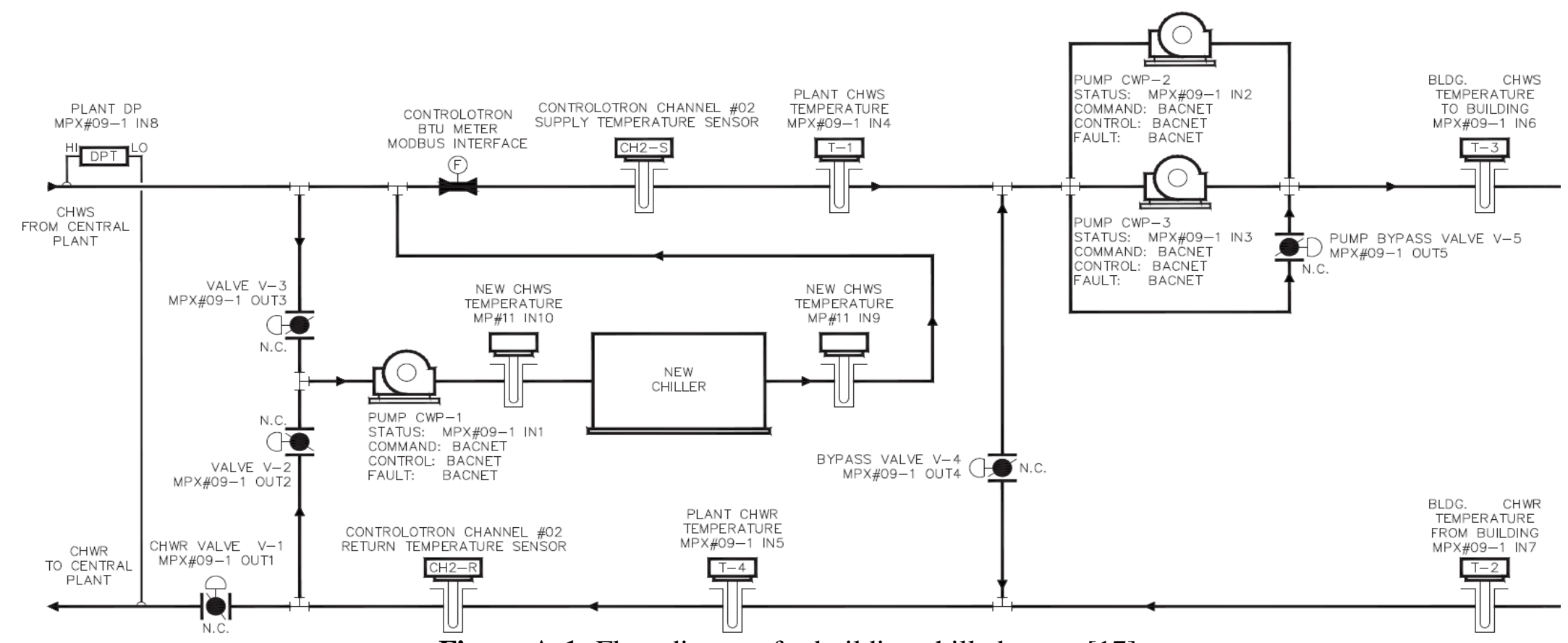

Figure A-1: Flow diagram for building chilled water [17]. 


\section{Appendix B: PA Air-Handling System Description}

The PA has a total of nine air-handling units, which were programmed with very similar control strategies. This Appendix uses AHU 1A to illustrate this control strategy. AHU 1A is a variable-air-volume system that was configured with enthalpy-based economizers. The AHU serves one-half of the auditorium, operating 24 hours per day, 7 days per week, without occupancy-based scheduling. Figure B-1 shows the flow diagram for AHU-1A.

The sequence of operations programmed in the AHU controller [17] specifies that the system maintain the supply air temperature (TS-1) downstream of the supply air fan at a setpoint temperature $20.5{ }^{\circ} \mathrm{C}\left(69{ }^{\circ} \mathrm{F}\right)$. Beginning from the left side of Figure B-1, unconditioned outside air enters the AHU and mixes with the air returned from the auditorium. The outside air fraction is controlled by the positions of the outside air and return air dampers, which are enthalpy-based economizing dampers controlled to make use of favorable outdoor air conditions (an outdoor enthalpy below $29.5 \mathrm{~kJ}$ (28 BTU) and outdoor air temperature at least $1.1{ }^{\circ} \mathrm{C}\left(2{ }^{\circ} \mathrm{F}\right)$ below the return air temperature). The minimum outdoor air damper position is $10 \%$ open to maintain minimum ventilation requirements and will be increased if the return air $\mathrm{CO}_{2}$ levels exceed $1440 \mathrm{mg} / \mathrm{m}^{3}$ (800 ppm). A mixed air temperature low limit prevents mixed air dropping below $7.2{ }^{\circ} \mathrm{C}$ $\left(45^{\circ} \mathrm{F}\right)$. The mixed air is filtered before passing over the heating coil and the cooling coil, where the air temperature may be adjusted to meet the desired setpoint temperature. The supply fan runs continuously during occupied periods and the control sequence modulates the output of the variable-frequency drive to maintain the airflow at the calculated setpoint. Depending on the call for cooling, the airflow values are reset between the minimum $0.92 \mathrm{~m}^{3} / \mathrm{s}$ (1950 SCFM) and maximum $2.6 \mathrm{~m}^{3} / \mathrm{s}$ (5480 SCFM) design values. 


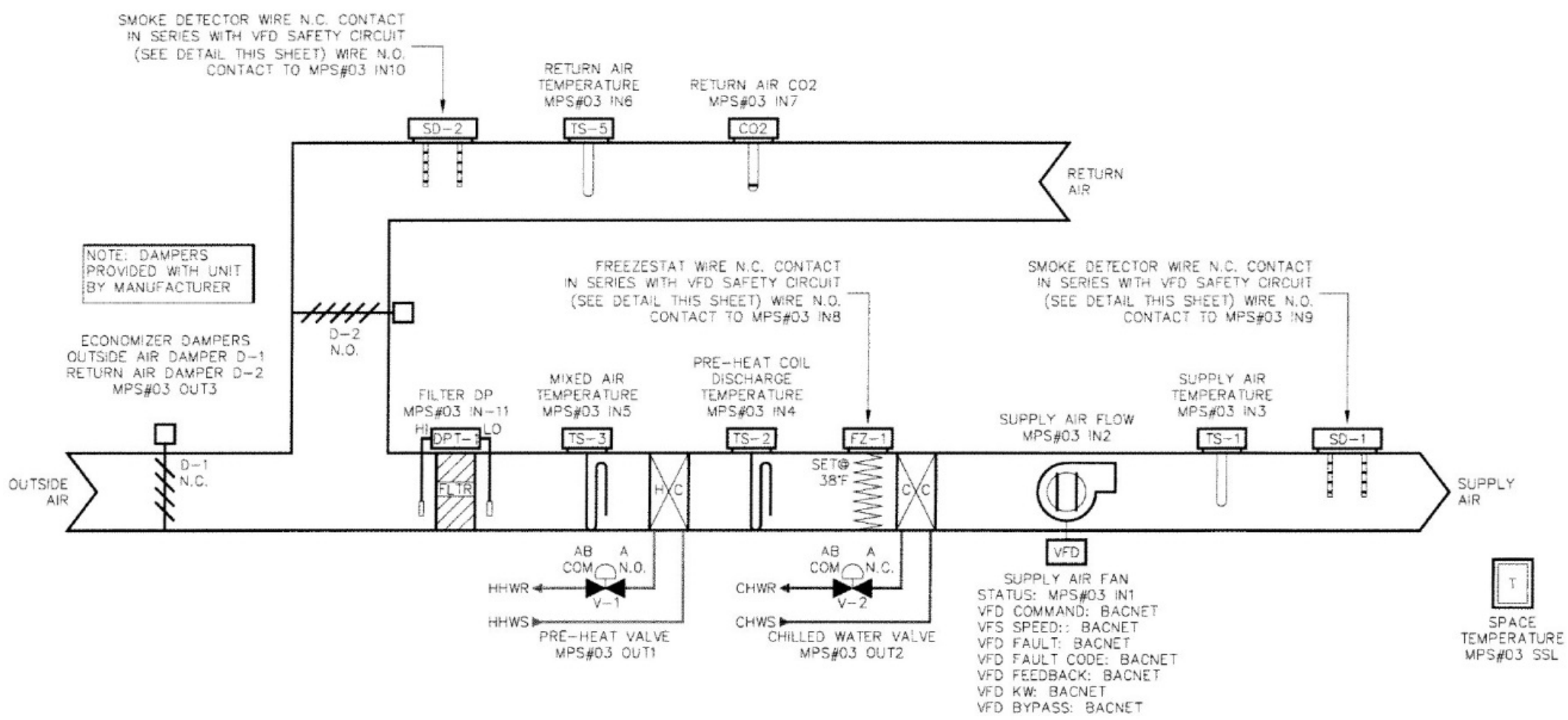

AIR HANDLING UNIT (AHU-1A) FLOW DIAGRAM SERVING: AUDITORIUM

Figure A-1: Flow diagram for AHU-1A [17]. 


\section{Appendix C: Library of Active Test Scripts}

A reference library of active test scripts (pre-functional test scripts and functional performance test scripts (FPTs)) for commissioning were developed to evaluate the chilled water loop and AHU operation. Where available, industry reference functional performance tests were used or adapted. Tests were further refined through interactions with the Cx Agent on the project. The test scripts provide basic checks at the component level and sensor level of the Air- Handling Units (AHUs) and the chilled water loop, but also address the overall performance of the systems. Pre-functional checks of the ancillary equipment are typically carried out as a prerequisite to carrying out FPTs for these systems and components. Test scripts are employed to facilitate this step, when possible. Because HVAC-Cx documents the tests scripts, along with the criteria for pass or failure, it also serves as a training tool for building operators, making operation more transparent. A calibrated reference sensor is used to validate reported values, as needed. General trending evaluation, such as trending damper control over a one- to two-day period with a oneminute interval, is carried out independently of HVAC-Cx.

Table C-1 describes the active tests, and lists the system or component being evaluated. In the case of the Performing Arts Center (PA), all nine air-handling units employed the same logic, except for two AHUs that do not have an outdoor air intake. Therefore, the test scripts developed for the first application are broadly valid for other AHUs.

Table C-1: List of Test Scripts to Retro-Cx the PA Chilled Water Distribution System

\begin{tabular}{|c|c|c|}
\hline Test Name & Description & Criteria for Passing \\
\hline $\begin{array}{l}\text { PF1 - plant supply } \\
\text { temp sensor }\end{array}$ & $\begin{array}{l}\text { Determine whether the plant supply } \\
\text { temperature sensor is reading the correct } \\
\text { value. }\end{array}$ & $\begin{array}{l}\text { The reported value matches the } \\
\text { value physically measured at the } \\
\text { system. }\end{array}$ \\
\hline $\begin{array}{l}\text { PF2 - bldg supply } \\
\text { temp sensor }\end{array}$ & $\begin{array}{l}\text { Determine whether the building supply } \\
\text { temperature sensor is reading the correct } \\
\text { value. }\end{array}$ & $\begin{array}{l}\text { The reported value matches the } \\
\text { value physically measured at the } \\
\text { system. }\end{array}$ \\
\hline $\begin{array}{l}\text { PF3 - bldg return } \\
\text { temp sensor }\end{array}$ & $\begin{array}{l}\text { Determine whether the building return } \\
\text { temperature sensor is reading the correct } \\
\text { value. }\end{array}$ & $\begin{array}{l}\text { The reported value matches the } \\
\text { value physically measured at the } \\
\text { system. }\end{array}$ \\
\hline $\begin{array}{l}\text { PF4 - plant return } \\
\text { temp sensor }\end{array}$ & $\begin{array}{l}\text { Determine whether the plant return } \\
\text { temperature sensor is reading the correct } \\
\text { value. }\end{array}$ & $\begin{array}{l}\text { The reported value matches the } \\
\text { value physically measured at the } \\
\text { system. }\end{array}$ \\
\hline $\begin{array}{l}\text { PF5 - entering } \\
\text { chiller temp sensor }\end{array}$ & $\begin{array}{l}\text { Determine whether the entering chiller } \\
\text { temperature sensor is reading the correct } \\
\text { value. }\end{array}$ & $\begin{array}{l}\text { The reported value matches the } \\
\text { value physically measured at the } \\
\text { system. }\end{array}$ \\
\hline $\begin{array}{l}\text { PF6 - leaving chiller } \\
\text { temp sensor }\end{array}$ & $\begin{array}{l}\text { Determine whether the leaving chiller } \\
\text { temperature sensor is reading the correct } \\
\text { value. }\end{array}$ & $\begin{array}{l}\text { The reported value matches the } \\
\text { value physically measured at the } \\
\text { system. }\end{array}$ \\
\hline $\begin{array}{l}\text { PF7 - chw bldg dp } \\
\text { sensor }\end{array}$ & $\begin{array}{l}\text { Determine whether the building } \\
\text { differential pressure sensor is reading the } \\
\text { correct value. }\end{array}$ & $\begin{array}{l}\text { The reported value matches the } \\
\text { value physically measured at the } \\
\text { system. }\end{array}$ \\
\hline $\begin{array}{l}\text { PF8 - chw plant dp } \\
\text { sensor }\end{array}$ & $\begin{array}{l}\text { Determine whether the plant differential } \\
\text { pressure sensor is reading the correct } \\
\text { value. }\end{array}$ & $\begin{array}{l}\text { The reported value matches the } \\
\text { value physically measured at the } \\
\text { system. }\end{array}$ \\
\hline PF9 - valve 1 & $\begin{array}{l}\text { Checks if valve opens and closes on } \\
\text { command. }\end{array}$ & $\begin{array}{l}\text { Opens and closes on command } \\
\text { (physical inspection needed). }\end{array}$ \\
\hline PF10 - valve 2 & $\begin{array}{l}\text { Checks if valve opens and closes on } \\
\text { command. }\end{array}$ & $\begin{array}{l}\text { Opens and closes on command } \\
\text { (physical inspection needed). }\end{array}$ \\
\hline
\end{tabular}




\begin{tabular}{|c|c|c|}
\hline Test Name & Description & Criteria for Passing \\
\hline PF11 - valve3 & $\begin{array}{l}\text { Checks if valve opens and closes on } \\
\text { command. }\end{array}$ & $\begin{array}{l}\text { Opens and closes on command } \\
\text { (physical inspection needed). }\end{array}$ \\
\hline PF12 - valve4 & $\begin{array}{l}\text { Checks if valve opens and closes on } \\
\text { command. }\end{array}$ & $\begin{array}{l}\text { Opens and closes on command } \\
\text { (physical inspection needed). }\end{array}$ \\
\hline PF13 - valve 5 & $\begin{array}{l}\text { Checks if valve opens and closes on } \\
\text { command. }\end{array}$ & $\begin{array}{l}\text { Opens and closes on command } \\
\text { (physical inspection needed). }\end{array}$ \\
\hline $\begin{array}{l}\text { PF14 - chw bypass } \\
\text { valve }\end{array}$ & $\begin{array}{l}\text { Checks if valve opens and closes on } \\
\text { command. }\end{array}$ & $\begin{array}{l}\text { Opens and closes on command } \\
\text { (physical inspection needed). }\end{array}$ \\
\hline PF15 - chw pump 1 & $\begin{array}{l}\text { Checks if pump stops and starts on } \\
\text { command. }\end{array}$ & $\begin{array}{l}\text { Starts and stops on command } \\
\text { (physical inspection needed). }\end{array}$ \\
\hline PF16 - chw pump 2 & $\begin{array}{l}\text { Checks if pump stops and starts on } \\
\text { command. }\end{array}$ & $\begin{array}{l}\text { Starts and stops on command } \\
\text { (physical inspection needed). }\end{array}$ \\
\hline PF17 - chw pump 3 & $\begin{array}{l}\text { Checks if pump stops and starts on } \\
\text { command. }\end{array}$ & $\begin{array}{l}\text { Starts and stops on command } \\
\text { (physical inspection needed). }\end{array}$ \\
\hline FPT1 - mode 1 & $\begin{array}{l}\text { Verifies the valve and pump sequences for } \\
\text { Mode } 1 .\end{array}$ & All valves close and pumps stop. \\
\hline $\begin{array}{l}\text { FPT2 - mode 2a and } \\
\text { chw available }\end{array}$ & $\begin{array}{l}\text { Verifies the valve and pump sequences for } \\
\text { Mode 2a and checks if chw is available } \\
\text { from the plant. }\end{array}$ & $\begin{array}{l}\text { Appropriate valves open for 2a, } \\
\text { pumps } 1-3 \text { do not turn on. Plant } \\
\text { supply water should be at the } \\
\text { discharge setpoint, within tolerance. }\end{array}$ \\
\hline FPT3 - mode 2b & $\begin{array}{l}\text { Verifies the valve and pump sequences for } \\
\text { Mode } 2 \mathrm{~b} \text {. }\end{array}$ & $\begin{array}{l}\text { Appropriate valves open for } 2 \text { b, } \\
\text { building pump } 2 \text { or } 3 \text { should come } \\
\text { on. }\end{array}$ \\
\hline FPT4 - mode 3a & $\begin{array}{l}\text { Verifies the valve and pump sequences for } \\
\text { Mode 3a. }\end{array}$ & $\begin{array}{l}\text { Appropriate valves open for 3a, } \\
\text { chiller comes on (physically } \\
\text { inspect), pump } 1 \text { on. }\end{array}$ \\
\hline FPT5 - mode 3b & $\begin{array}{l}\text { Verifies the valve and pump sequences for } \\
\text { Mode } 3 b \text {. }\end{array}$ & $\begin{array}{l}\text { Appropriate valves open for } 3 b \text {, } \\
\text { chiller comes on (physically } \\
\text { inspect), pump } 1 \text { on, either pump } 2 \\
\text { or } 3 \text { on . }\end{array}$ \\
\hline FPT6 - mode 4 & $\begin{array}{l}\text { Verifies the valve and pump sequences for } \\
\text { Mode } 4 .\end{array}$ & $\begin{array}{l}\text { Appropriate valves open for } 4 \text {, } \\
\text { chiller comes on (physically } \\
\text { inspect), pump } 1 \text { on, either pump } 2 \\
\text { or } 3 \text { on, V-1 shut. }\end{array}$ \\
\hline $\begin{array}{l}\text { FPT7 - mode } 2 \mathrm{~V}-1 \\
\text { modulation }\end{array}$ & $\begin{array}{l}\text { Verifies that V-1 modulates to maintain } \\
\text { temperature difference across building. }\end{array}$ & $\begin{array}{l}\text { In Mode } 2 \text { a with a call for cooling, } \\
\text { valve } 1 \text { should close as necessary to } \\
\text { maintain a } 8.4^{\circ} \mathrm{C}\left(15^{\circ} \mathrm{F}\right) \max \\
\text { temperature difference across the } \\
\text { building pipes. }\end{array}$ \\
\hline $\begin{array}{l}\text { FPT8 - VFD } \\
\text { modulation for min } \\
\text { flow }\end{array}$ & $\begin{array}{l}\text { Verifies that the vfd bypass valve opens as } \\
\text { necessry to prevent overpressurization. }\end{array}$ & $\begin{array}{l}\text { In Mode 3b with no calls for } \\
\text { cooling. The should open when } \\
\text { plant dp increase to } 172 \mathrm{kPa} \\
\text { ( } 25 \text { psi). }\end{array}$ \\
\hline
\end{tabular}


Table C-2: List of Active Test Scripts to Retro-Cx the PA Air-Handling System.

\begin{tabular}{|c|c|c|}
\hline Test Name & Description & Criteria for passing \\
\hline $\begin{array}{l}\text { PF1 - check SA } \\
\text { temp sensor }\end{array}$ & $\begin{array}{l}\text { Determine whether the supply air } \\
\text { temperature sensor is reading the correct } \\
\text { value. }\end{array}$ & $\begin{array}{l}\text { The reported value matches the } \\
\text { value physically measured at the } \\
\text { system. }\end{array}$ \\
\hline $\begin{array}{l}\text { PF2 - check MA } \\
\text { temp sensor }\end{array}$ & $\begin{array}{l}\text { Determine whether the mixed air } \\
\text { temperature sensor is reading the correct } \\
\text { value. }\end{array}$ & $\begin{array}{l}\text { The reported value matches the } \\
\text { value physically measured at the } \\
\text { system. }\end{array}$ \\
\hline $\begin{array}{l}\text { PF3 - check RA } \\
\text { temp sensor }\end{array}$ & $\begin{array}{l}\text { Determine whether the return air } \\
\text { temperature sensor is reading the correct } \\
\text { value. }\end{array}$ & $\begin{array}{l}\text { The reported value matches the } \\
\text { value physically measured at the } \\
\text { system. }\end{array}$ \\
\hline $\begin{array}{l}\text { PF4 - check RA } \\
\mathrm{CO}_{2} \text { sensor }\end{array}$ & $\begin{array}{l}\text { Determine whether the return air carbon } \\
\text { dioxide sensor is reading the correct value. }\end{array}$ & $\begin{array}{l}\text { The reported value matches the } \\
\text { value physically measured at the } \\
\text { system. }\end{array}$ \\
\hline $\begin{array}{l}\text { PF5 - check filter } \\
\text { dp sensor }\end{array}$ & $\begin{array}{l}\text { Determine whether the filter differential } \\
\text { pressure sensor is reading the correct } \\
\text { value. }\end{array}$ & $\begin{array}{l}\text { The reported value matches the } \\
\text { value physically measured at the } \\
\text { system. }\end{array}$ \\
\hline PF6 - Heating coil & $\begin{array}{l}\text { Verify that the heating coil can open and } \\
\text { close as well as heat the air moving across } \\
\text { it. }\end{array}$ & $\begin{array}{l}\text { Supply air temperature rises when } \\
\text { valve opens, valve physically opens. } \\
\text { Temperature returns to previous } \\
\text { value when valve closes, valve } \\
\text { physically closes. }\end{array}$ \\
\hline PF7 - Cooling coil & $\begin{array}{l}\text { Verify that the cooling coil can open and } \\
\text { close as well as cool the air moving across } \\
\text { it. }\end{array}$ & $\begin{array}{l}\text { Supply air temperature drops when } \\
\text { valve opens, valve physically opens. } \\
\text { Temperature returns to previous } \\
\text { value when valve closes, valve } \\
\text { physically closes. }\end{array}$ \\
\hline $\begin{array}{l}\text { PF8 - OA/RA } \\
\text { damper }\end{array}$ & $\begin{array}{l}\text { Verify that the damper opens and closes } \\
\text { fully, lets in outside air. }\end{array}$ & $\begin{array}{l}\text { OA damper goes to } 0 \text { when RA is at } \\
100 \text { and vice versa. Mixed air temp } \\
\text { rises when OA damper is open. }\end{array}$ \\
\hline PF9 - fan operation & $\begin{array}{l}\text { Verify that the fan can shut on and off } \\
\text { fully. }\end{array}$ & $\begin{array}{l}\text { Fan shuts off completely (verify in } \\
\text { person) when commanded and } \\
\text { opens fully. }\end{array}$ \\
\hline $\begin{array}{l}\text { FPT1 - Change OA } \\
\text { damper sp }\end{array}$ & $\begin{array}{l}\text { Check that the OA damper responds to a } \\
\text { change in the minimum OA damper sp. }\end{array}$ & $\begin{array}{l}\text { The OA damper position changes to } \\
\text { the new setpoint (if not doing } \mathrm{CO}_{2} \\
\text { control or economizing). }\end{array}$ \\
\hline $\begin{array}{l}\text { FPT2 - RA smoke } \\
\text { safety }\end{array}$ & $\begin{array}{l}\text { Trigger smoke alarm and see if system } \\
\text { shuts down. }\end{array}$ & $\begin{array}{l}\text { All valves close, fan stops, and } \\
\text { dampers close. }\end{array}$ \\
\hline $\begin{array}{l}\text { FPT3 - SA smoke } \\
\text { safety }\end{array}$ & $\begin{array}{l}\text { Trigger smoke alarm and see if system } \\
\text { shuts down. }\end{array}$ & $\begin{array}{l}\text { All valves close, fan stops, and } \\
\text { dampers close. }\end{array}$ \\
\hline $\begin{array}{l}\text { FPT4 - response to } \\
\text { occupancy }\end{array}$ & $\begin{array}{l}\text { System turns on when occupied and off } \\
\text { when not. }\end{array}$ & $\begin{array}{l}\text { Valves close, fan stops, and } \\
\text { dampers close when unoccupied and } \\
\text { turn back on when occupied. }\end{array}$ \\
\hline $\begin{array}{l}\text { FPT5 - night } \\
\text { setback and setup } \\
\text { responses }\end{array}$ & $\begin{array}{l}\text { Determines if system maintains its } \\
\text { unoccupied setpoints. }\end{array}$ & $\begin{array}{l}\text { Heating coil turns on when temp is } \\
\text { below setpoint. Cooling coil turns } \\
\text { on when temp is above setpoint. }\end{array}$ \\
\hline $\begin{array}{l}\text { FPT6 - MA safety } \\
\text { test }\end{array}$ & $\begin{array}{l}\text { System responds appropriately to mixed } \\
\text { air that's too cold. }\end{array}$ & $\begin{array}{l}\text { Heating coil opens and OA damper } \\
\text { shuts when mixed goes below sp. }\end{array}$ \\
\hline $\begin{array}{l}\text { FPT7- Enthalpy- } \\
\text { activated } \\
\text { economizing }\end{array}$ & $\begin{array}{l}\text { Checks that system activates economizer } \\
\text { mode in response to adequate outdoor air } \\
\text { enthalpy. }\end{array}$ & $\begin{array}{l}\text { Check that air-handlers open } \\
\text { outdoor air dampers and have } \\
\text { economizing enabled. }\end{array}$ \\
\hline
\end{tabular}

